\title{
The Palaeo-Eskimo Prehistory of the North Devon Lowlands
}

\author{
JAMES W. HELMER ${ }^{1}$
}

(Received 5 June 1990; accepted in revised form 5 March 1991)

\begin{abstract}
In this paper the distinguishing characteristics of six chronologically discrete Palaeo-Eskimo occupations discovered in the North Devon Lowlands region of Devon Island, Northwest Territories, are summarized and their cultural/chronological positions briefly assessed. Observed variations in the intensity of occupation in the study area and major shifts in the extra-regional cultural affiliations of these six occupational episodes are discussed in reference to a high-mobility subsistence/settlement strategy model of High Arctic Palaeo-Eskimo socioecological adaptations.

Key words: Arctic, Devon Island, prehistory, Palaeo-Eskimo, Pre-Dorset, Dorset

RÉSUMÉ. Cet article présente un résumé des traits distinctifs de six sites paléo-esquimaux distincts au plan chronologique, découverts dans la région septentrionale des terres basses Devon de l'île Devon (Territoires du Nord-Ouest), et il en évalue sommairement la position culturelle et chronologique. Il discute des variations observées dans l'intensité de l'occupation de la zone d'étude et des mouvements importants dans les affiliations culturelles extra-régionales de ces six épisodes d'occupation, en rapport avec un modèle de stratégie de subsistance/colonisation, fondée sur une grande mobilité, modèle portant sur les adaptations socio-écologiques des Paléo-Esquimaux de l'Extrême-Arctique.

Mots clés: Arctique, île Devon, préhistoire, paléo-esquimau, pré-Dorset, Dorset

Traduit pour le journal par Nésida Loyer.
\end{abstract}

\section{INTRODUCTION}

The North Devon Lowlands are located on the northeastern shore of Devon Island in the central Canadian High Arctic (Fig. 1). They comprise four tightly clustered, but nonetheless discrete, lowland areas - the Sverdrup, Sparbo-Hardy, Skogn and Truelove lowlands - each separated by dominant headlands of Pre-Cambrian age metamorphic rocks.

The four lowlands are characterized by unusually lush vegetation cover and a comparatively high terrestrial mammal biomass (Bliss, 1977). In sharp contrast, a majority of the surrounding exposed land surfaces is classified as polar desert or semi-desert (Babb and Bliss, 1974). These latter areas have little or no vegetation cover and support few resident land mammals. Lowland biotic zones, such as the North Devon Lowlands, are rare, highly localized phenomena in the High Arctic and are considered to be of major ecological significance (Babb and Bliss, 1974; Bliss, 1977).

In 1982, members of the Department of Archaeology at the University of Calgary initiated a six-year program of archaeological research in the North Devon Lowlands region (Helmer, 1984, 1987a). The principal objective of the Devon Island Archaeology Project (DIAP) was to determine if the study area was a significant locus for the seasonal exploitation of terrestrial mammal resources by the prehistoric Early and Late Palaeo-Eskimo peoples who occupied the Eastern Canadian Arctic ca. $4500-1000$ years before present (B.P.). Additional research goals included the analysis of seasonal, functional and/or cultural variations in Palaeo-Eskimo material culture and subsistence/settlement systems. In this paper, the main features of the sequence of multiple Palaeo-Eskimo occupations of the North Devon Lowlands are described and the nature of this occupational sequence relative to current perspectives on High Arctic Palaeo-Eskimo prehistory is assessed.

\section{THE DEVON ISLAND ARCHAEOLOGY PROJECT}

The Devon Island Archaeology Project (1982-87) involved both the comprehensive site survey of the North Devon
Lowlands region and the full-scale excavation of selected habitation features in sites recognized to be of cultural historical significance. The site survey component of this project involved examining in close detail the entire coastline of the study area between Truelove Inlet and the Sverdrup Glacier (Helmer, 1990, in press). In addition, numerous judgemental transects were walked through the wet lowland interiors.

Between 1982 and 1987, 163 archaeological sites were located in the study area (Helmer, 1990, in press). These contain evidence of a minimum of 184 discrete components and span as much as 4500 years of occupational history (Table 1 ). Twenty-two of the 184 identified components are of confirmed Early Palaeo-Eskimo (ca. 4500-3000 B.P.) affiliation. Six others are associated with the Late Palaeo-Eskimo stage (ca. 3000-1000 B.P.). Twenty-five additional components, though clearly of Palaeo-Eskimo affiliation, could not be more precisely identified.

Twenty-one habitation features from nine of the confirmed Early and Late Palaeo-Eskimo sites were fully excavated (Fig. 2). Features at six other sites were tested or surface collected. Approximately 4600 lithic and organic tools (excluding debitage) and 16600 animal bones and bone fragments were recovered during this phase of the project.

An informal comparative analysis of the individual assemblages recovered from the 15 sampled sites, supplemented by an assessment of 13 radiometric assays, relative beach ridge elevations and the quantitative analyses of selected artefact groups (Robertson, 1989; Helmer and Robertson, 1990), has led to the identification of six discrete Palaeo-Eskimo occupations in the study area (Table 2). These include four Early Palaeo-Eskimo and two Late Palaeo-Eskimo occupations. Each occupational episode is represented by a polythetic complex of attributes (Rouse, 1972:238) shared by two or more features from one or more sites. What follows is a summary of the principal habitational, economic and artefactual characteristics of the six North Devon Lowland Palaeo-Eskimo "complexes" and an assessment of their relative cultural and chronological positions. 


\section{THE EARLY PALAEO-ESKIMO OCCUPATIONS OF THE NORTH DEVON LOWLANDS}

\section{The Far Site Complex}

The Far Site Complex constitutes the earliest recorded human occupation of the study area. It is represented by an assemblage of approximately 480 artefacts obtained from three excavated and/or tested sites. These include the Far Site (QkHn-22), which is considered the "type site" for this com- plex, the Gneiss Site (QkHn-8) and the Over Site (QkHn-15). All three are situated on raised beach "pockets" ranging in elevation from 12 to $16 \mathrm{~m}$ above sea level (asl).

A variety of different habitation features is associated with the Far Site Complex. Three semi-subterranean dwellings (two of which were excavated) were discovered at QkHn-22. These structures are circular in outline, with a very slightly raised berm around the lip of the depression (Fig. 3). They measure approximately $3 \mathrm{~m}$ in diameter and $30-50 \mathrm{~cm}$ in depth.

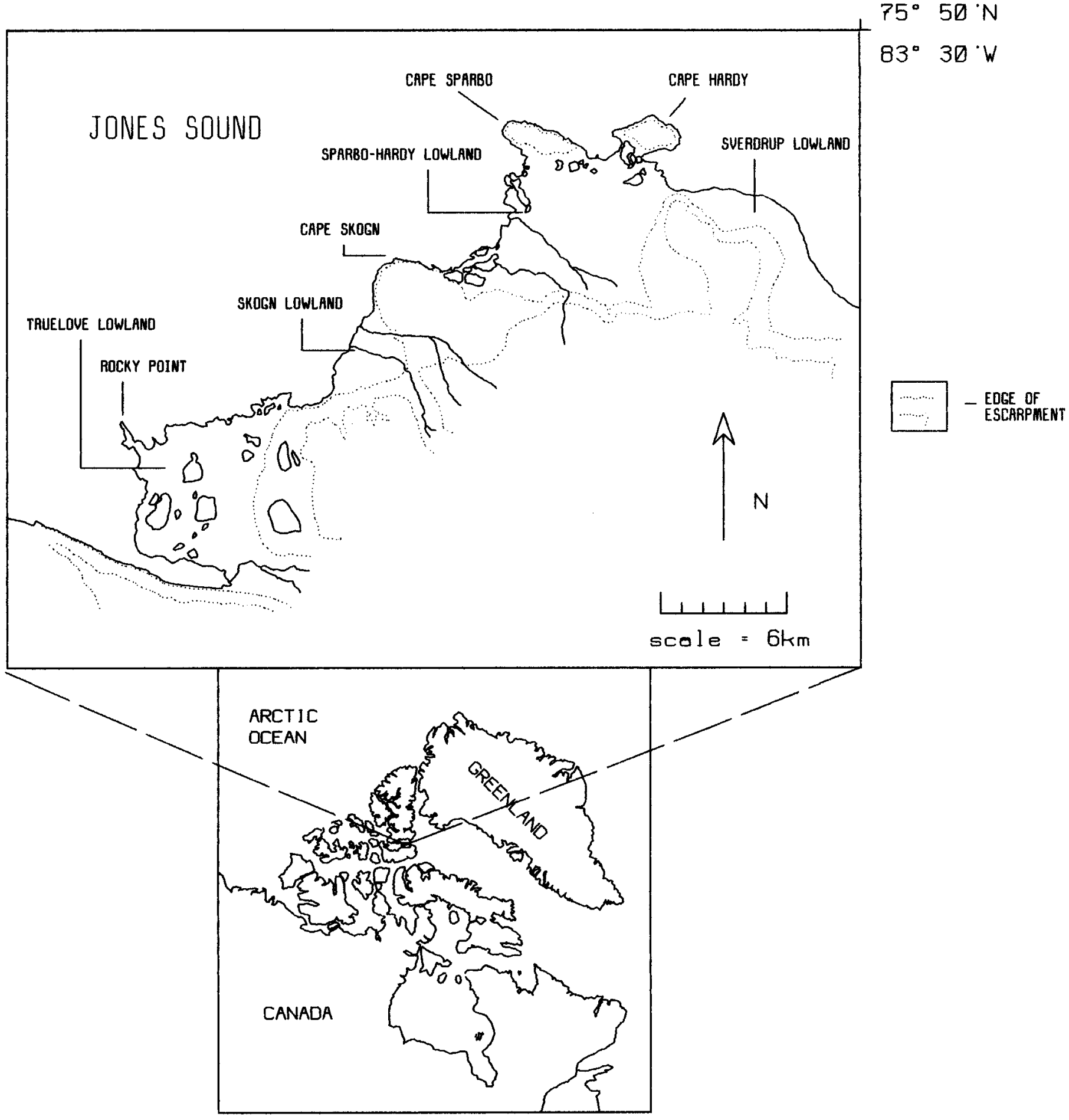


Clusters of rocks in the centres of these depressions are presumably the remnants of small hearths.

A second structure type found at the Far Site consists of a large amorphous boulder ring $\mathrm{ca} .4 \mathrm{~m}$ in diameter (Fig. 4). A possible interior hearth area occurs near the periphery of the ring. Six examples of this structure type were recorded at QkHn-22.

Several small boulder tent rings with well-defined central mid-passages occur at QkHn-8 and QkHn-15. These roughly oval structures are each bisected by two parallel rows of small rounded boulders set $c a .50 \mathrm{~cm}$ apart. Rectangular hearth areas framed by boulders are situated near the centres of these midpassages.

TABLE 1. Breakdown of archaeological components in the North Devon Lowlands by cultural affiliation (Helmer, 1990)

\begin{tabular}{lc}
\hline \hline Affiliation & \# components \\
\hline Palaeo-Eskimo $^{*}$ & 25 \\
Early Palaeo-Eskimo & 22 \\
Late Palaeo-Eskimo & 6 \\
Thule & 41 \\
Historic Inuit & 25 \\
Unidentified & 65 \\
Total & 184 \\
\hline
\end{tabular}

"Label assigned to components with associated surface chert flaking debris but no diagnostic formed tools.
Virtually no identifiable faunal remains were recovered from the excavated Far Site Complex habitation features. As well, no midden deposits were discovered in association. While extremely poor organic preservation likely accounts in large part for the lack of bone material, a majority of these features were probably not occupied long enough or often enough to have accumulated much midden debris.

In the absence of faunal data it is impossible to establish the season (or seasons) of occupation for the excavated Far Site Complex features. The presence of semi-subterranean houses at QkHn-22, though, is suggestive of a cold season settlement, perhaps during the late fall and/or early winter.

The combined Far Site Complex artefact assemblage contains large triangular endblades with finely serrated margins (Fig. 5:a-f), large, unserrated, triangular bifaces (Fig. 5:g-h) and both large- and small-stemmed, or bi-pointed, bifaces (Fig. 5:i-j). Ovate sideblades (Fig. 5:k-1), large stemmed, triangular and oblique end scrapers (Fig. 5:m-p), very large concave side scrapers (one of which is broadly serrated) (Fig. 5: q-t), large unifacial and bifacial burins (Fig. 5:u-z), a very well-made polished adze blade (Fig. 5:ee) and numerous rather wide microblades (Fig. 5:aa-bb) also occur. Only two organic artefacts, both fragments of worked walrus ivory, were recovered from the excavated Far Site Complex features.

Three radiocarbon dates, all run on driftwood charcoal samples, were obtained from three discrete habitation features - two from hearth areas in the excavated semi-subterranean features at QkHn-22 and a third from the mid-passage area of

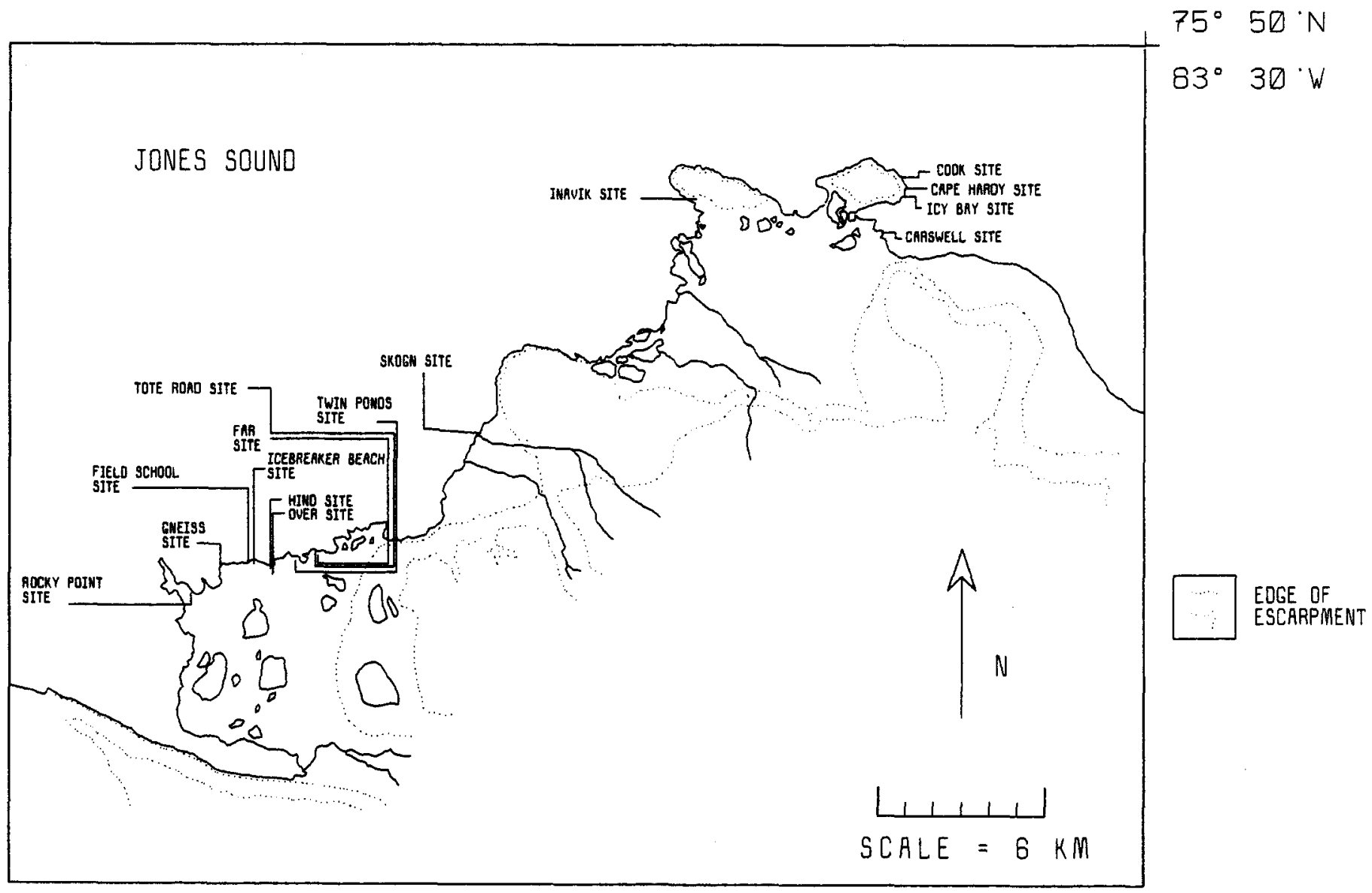

FG. 2. Locations of the nine excavated Palaeo-Eskimo sites mentioned in the text. 
Feature 1 at QkHn-8 (Table 2). The mean estimates of these three tightly clustered dates fall between 4000 and 4200 B.P.

Typologically, the Far Site Complex bears a strong resemblance to the Early Palaeo-Eskimo Independence I "culture" of northeast Greenland (Knuth, 1967, 1977/78), northeastern Ellesmere Island (McCullough and Schledermann, 1989; Schledermann, 1978a, 1987, 1990; Schledermann and McCullough, 1988a,b) and northwestern Devon Island
(McGhee, 1976, 1979). It is also comparable to the Independence I-related Early Pre-Dorset complex of northern Labrador (Tuck, 1975; Cox, 1978).

Specific attributes shared by the Far Site Complex and these Independence I-related components include the fineedge serration of endblades, multiple notching at the base of some burins and concave side scrapers and the overall large size of individual stone tools. Lacking in the Far Site

TABLE 2. Sites, features, elevations and radiocarbon dates (uncalibrated) representing the six Palaeo-Eskimo complexes identified in the North Devon Lowlands

Early Palaeo-Eskimo Occupations

\begin{tabular}{lccccc} 
Site/Feature & Type $^{1}$ & $\begin{array}{c}\text { Elev. } \\
(\mathrm{m} \mathrm{as})^{2}\end{array}$ & Date $^{3}$ & Lab\# $^{4}$ & Material \\
\hline Far Site Complex & & & & & \\
QkHn-8:1\&2 & AP & $15-16$ & $4160 \pm 180$ & B-12405 & Unknown - driftwood? \\
QkHn-22:10 & OD & $14-15$ & $4110 \pm 90$ & B-20783 & Driftwood \\
QkHn-22:1 & OD & $14-15$ & $4040 \pm 70$ & B-12406 & Driftwood count \\
QkHn-22:8 & OTR & $14-15$ & N/A & & Standard count \\
QkHn-15:1\&2 & AP & 12 & N/A & &
\end{tabular}

Icebreaker Beach Complex

$\begin{array}{lcccl}\text { QkHn-13:14 } & \text { OTR } & 8-9 & 4500 \pm 80^{*} & \text { B-20782 } \\ \text { QkHn-13:4 } & \text { OTR } & 8-9 & 3850 \pm 95 & \text { S-1313 } \\ \text { QkHl-5:3 } & \text { AP/OTR } & 8-9 & 3770 \pm 180 & \text { B-20781 } \\ \text { QkHn-38:4 } & \text { UID } & 7-8 & 3700 \pm 70 & \text { B-25032 } \\ \text { QkHn-38:4 } & \text { UID } & 7-8 & 2880 \pm 190^{*} & \text { B-15394 } \\ \text { QkHn-13:1 } & \text { OTR? } & 7-8 & \text { N/A } & \\ \text { QkHn-13:15 } & \text { UID } & 7-8 & \text { N/A } & \\ \text { QkHl-5:2 } & \text { AP/OTR } & 7-8 & \text { N/A } & \end{array}$

\section{Driftwood? Unburned caribou bone Driftwood \\ Unburned caribou bone Unknown wood carbon}

$\begin{array}{cc}4070 \pm 80^{*} & \text { B-20780 } \\ 3680 \pm 90 & \text { B-15390 } \\ 3535 \pm 90 & \text { B-15389 } \\ \text { N/A } & \\ \text { N/A } & \\ \text { N/A } & \end{array}$

$4060 \pm 80^{*}$ $3800 \pm 90^{*}$
B-16554
B-15391

\section{Driftwood? Driftwood? Unknown wood carbon}

Standard count Bone collagen Extended count Bone collagen Extended count

Rocky Point Complex

$\begin{array}{llllll}\text { QkHn-27:15 } & \text { ATR } & 6-7 & 4060 \pm 80^{*} & \text { B-16554 } & \text { Unknown wood carbon } \\ \text { QkHn-27:17 } & \text { ATR } & 6-7 & 3800 \pm 90^{*} & \text { B-15391 } & \text { Possible willow carbon }\end{array}$

AMS

Extended count

\section{Late Palaeo-Eskimo Complexes}

Cape Hardy Complex

\begin{tabular}{|c|c|c|c|c|c|c|}
\hline QkHn-37:1 & RTR & $2-4$ & $2710 \pm 60$ & B-15393 & Driftwood & Standard count \\
\hline QkHm-14 & $\mathrm{AP}$ & $2-4$ & N/A & & & \\
\hline QkHL-4 & N/A & $2-3$ & N/A & & & \\
\hline \multicolumn{7}{|c|}{ ridge Complex } \\
\hline QkHL-2 & N/A & $2-4$ & N/A & & & \\
\hline QkHL-3 & $\mathrm{LH}$ & $2-4$ & N/A & & & \\
\hline QkHn-12 & N/A & $2-4$ & N/A & & & \\
\hline
\end{tabular}

'Codes for feature types: AP = axial-passage tent ring; AP/OTR = possible axial passage or ovate tent ring; ATR = amorphous tent ring; LH = longhouse feature; $\mathrm{MP}=$ mid-passage tent ring; $\mathrm{OD}=$ ovate depression; OTR = ovate tent ring; $\mathrm{RTR}=$ rectangular tent ring; UID = unidentified feature type; N/A = no associated habitation feature.

${ }^{2} \mathrm{~m}$ asl $=$ metres above sea level.

${ }^{3}$ All dates are expressed in radiocarbon years before present. With the exception of sample B-25032 (QkHn-38:4), all dates have been corrected for C12/C13 fractionation. Dates marked with an asterisk $(*)$ are considered problematic.

${ }^{4}$ All dates were processed by Beta Analytic except for sample S-1313 from QkHn-13 Feature 4, which was processed by the Canadian Museum of Civilization. 
Complex, however, are the bi-pointed endblades and taperedstem bifaces that so strongly characterize Independence I and Labrador Early Pre-Dorset assemblages.

Independence I components from northeast Greenland and northwest Devon Island have been dated, on wood charcoal, to 4360-3620 B.P. (mean age estimates; see McGhee, 1979:124). Comparable dates apply to Independence I components from east-central Ellesmere Island and to northern Labrador Early Pre-Dorset components (Cox, 1978:99; Schledermann, 1987:2). These dates are all consistent with the $4200-4000$ B.P. mean age estimates obtained from Far Site Complex contexts in the North Devon Lowlands.

\section{The Icebreaker Beach Complex}

Evidence of an Early Pre-Dorset occupation, believed to be slightly more recent than the Far Site Complex, was found in eight excavated features from three different sites in the study area. Two of these sites, the Icebreaker Beach Site (QkHn-13) and the Hind Site (QkHn-38), are located in the Truelove Lowland. The third, the Icy Bay Site (QkHl-05), occurs in the Sparbo-Hardy Lowlands. All three are situated on fossil beaches ranging in elevation from 7 to $9 \mathrm{~m}$ asl. The Icebreaker Beach Site is considered the type site for this complex.

Habitation features associated with the Icebreaker Beach Complex tend to be large $(4.5 \times 4 \mathrm{~m})$ oval tent rings with one or more interior hearths (Fig. 6). No well-defined axial pas-

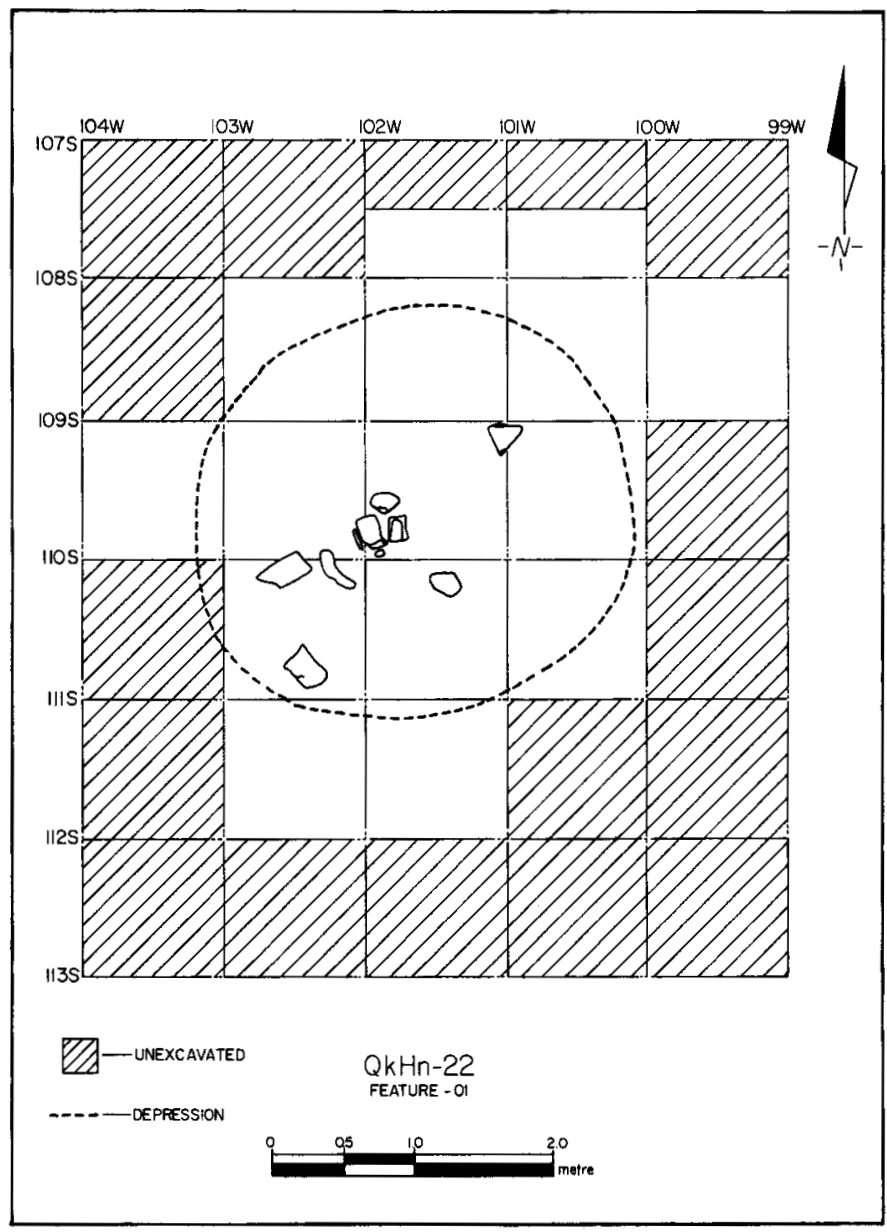

sage structures have been identified, though several disturbed features may once have had such interior arrangements.

One particularly interesting feature (QkHn-38 Feature 4) associated with this complex is an oval scatter of artefacts and faunal materials measuring $c a .3 .5 \times 3 \mathrm{~m}$. Small concentrations of wood charcoal found within this oval area have been interpreted as the remnants of two or more small hearths. Given the shape and density of the associated artefact scatter, this feature may well represent the remains of a temporary snow shelter (McGhee, 1979:125).

A substantial assemblage of animal bones ( $\mathrm{N}=7061$ identifiable specimens) was recovered from the excavated Icebreaker Beach Complex features. McCartney (1989) has demonstrated that there is no significant between-feature variation in the species composition of the individual faunal samples.

The remains of small seals, probably ringed seals (Phoca hispida), constitute $65.5 \%$ of the combined faunal assemblage. Caribou remains account for $12 \%$ of the collection and various orders of birds (including waterfowl and shorebirds) a further $14 \%$. Other animal taxa represented in the Icebreaker Beach Complex faunal assemblage include whale, walrus, polar bear, musk-ox, large canid (quite possibly dog), fox, hare and fish.

Analysis of seal tooth thin sections suggests that the excavated Icebreaker Beach Complex features were occupied between April and February (McCartney, 1989). The most active period of use, though, appears to have been between August and November. In evaluating these seasonal data, it is important to bear in mind that individual features may very well have been occupied more than once and at different seasons of the year.

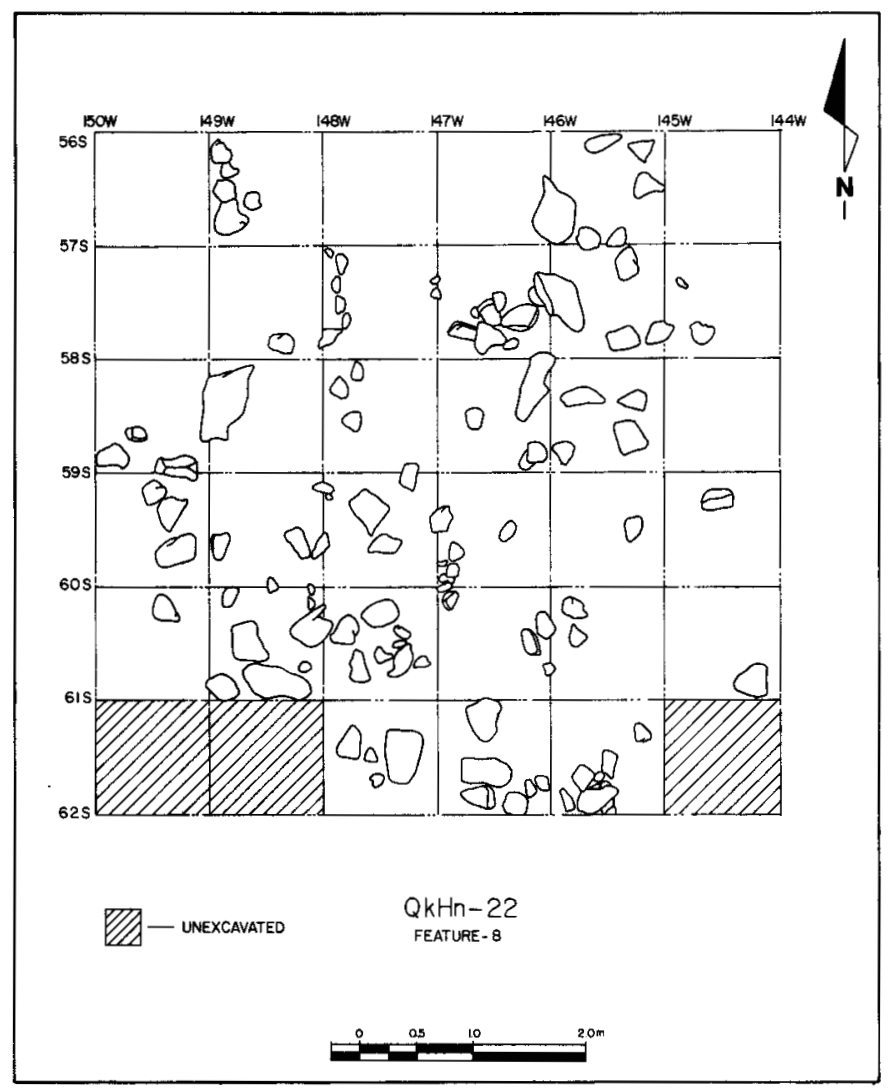

FIG. 4. Plan of QkHn-22 Feature 8 (Far Site Complex). 
A combined total of $c a .2010$ artefacts was obtained from the eight excavated Icebreaker Beach Complex features. Preservation at QkHn-13 (the type site) itself was exceptionally good. As a result organic tools, which are generally rare in Early Palaeo-Eskimo contexts, are well represented.

The Icebreaker Beach Complex lithic assemblage is characterized by narrow, straight-based, triangular endblades (Fig. 7:a-f), unserrated, bi-pointed endblades (Fig. 7:g-i), large and
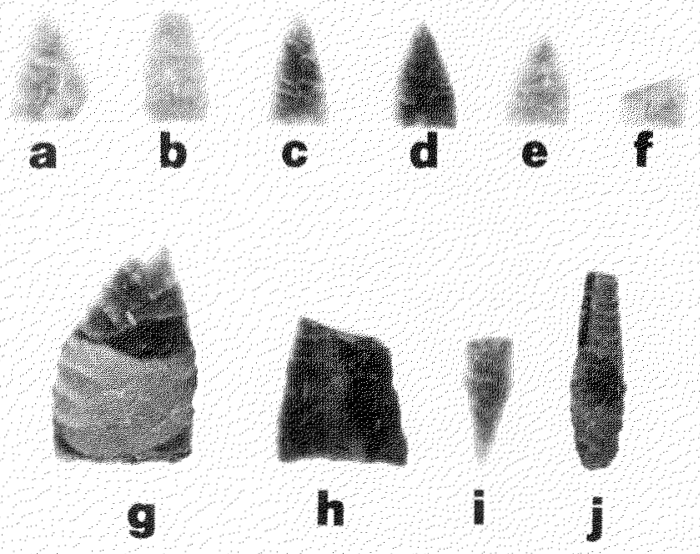

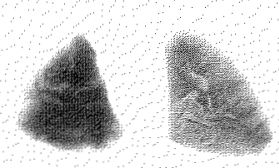

k

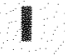

1
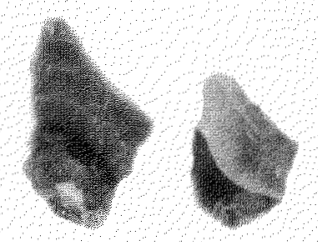

9
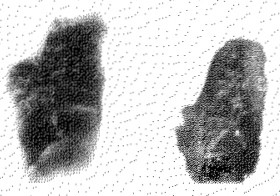

$r$
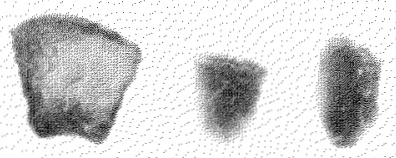

m

II

0

p

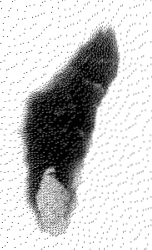

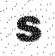
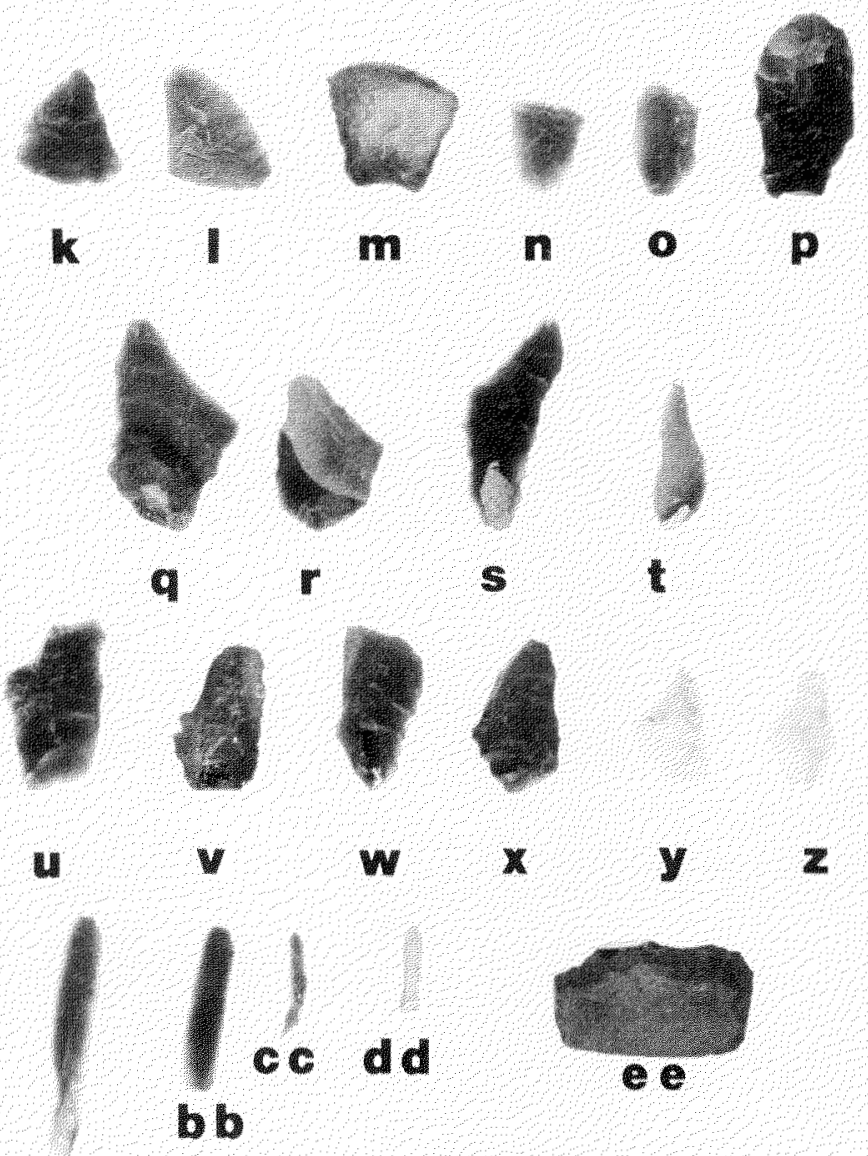

a a
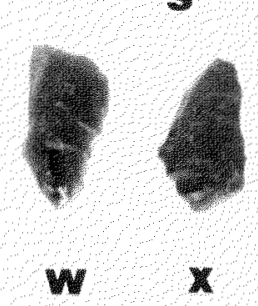

$x$

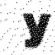

2 small straight-stemmed and tapered-stem bifaces (Fig. 7:j-p), a variety of flake knife forms (Fig. 7:q-u), large and small ovate sideblades (Fig. 7:v-z), large and small end scrapers (Fig. 7:aa-ee), concave side scrapers (Fig. 7:ff-ii), a wide variety of rather small burins (Fig. 7:jj-oo), ground adze blades (Fig. 7:tt-uu) and the ubiquitous microblades and burin spalls (Fig. 7:pp-ss). Organic artefacts of note include tang-based, unilaterally barbed, non-toggling harpoon heads with endblade insets (Fig. 8:a-b), flat, self-bladed, open-socketed toggling harpoon heads (Fig. 8:c-d), a lance foreshaft (?) with sideblade insets (Fig. 8:g), a variety of harpoon foreshafts (Fig. 8:j,1), darts, barbs and fish spears (Fig. 8:e,i,m), an arrow foreshaft (Fig. 8:f), a throwing board section (Fig. 8:h), a whalebone bilobate bowl (Fig. 8:r), a piece of geometrically decorated bone and a large number of cylindrical needles with round eyelets (Fig. 8:p-q).

The most dramatic artefact associated with this early PreDorset occupation is a small ivory carving of a human face discovered in Feature 1 at QkHn-13 (Fig. 9). The figure portrayed is thought to be that of an elderly (perhaps deceased) arctic Mongoloid woman (Helmer, 1986a). This artefact, one of the oldest known examples of Early Palaeo-Eskimo representational art, clearly demonstrates that the roots of the

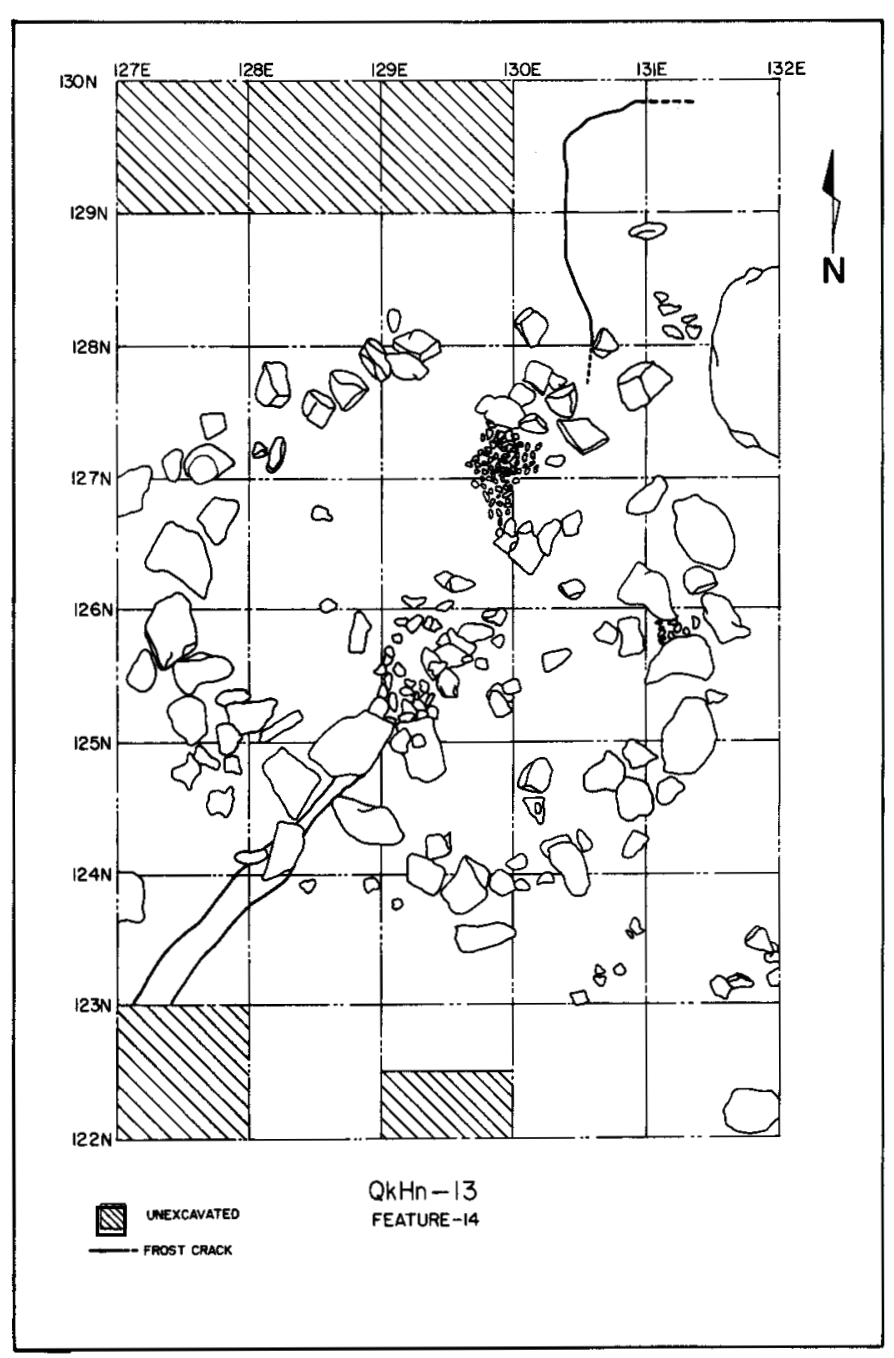

FIG. 6. Plan of QkHn-13 Feature 14 (Icebreaker Beach Complex).

FIG. 5. Selected artefacts from Far Site Complex assemblages: a-f) triangular endblades with fine edge serration; $g-h$ ) large triangular bifaces; $i-j$ ) taperedstem bifaces; $k-1)$ miscellaneous sideblade fragments; $m-p$ ) end scrapers; $q-t$ ) concave side scrapers; $u-z$ ) burins; aa-bb) microblades; $c c-d d$ ) burin spalls; ee)

adze fragment.

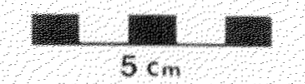


Dorset artistic tradition lie in the earliest stages of the Arctic Small Tool tradition.

A suite of five radiocarbon dates was obtained from four of the eight Icebreaker Beach Complex features (Table 2). Two of these assays were run on unburned caribou bone. Two others are extended count dates run on very small charcoal samples - one of burned driftwood and the other of charred arctic willow. The fifth date is a standard count assay run on a large piece of driftwood charcoal. The mean estimates of these dates range from 2800 to 4500 B.P.

The upper and lower estimates for this temporal range are problematic. The upper limit, set by an extended count wood charcoal date of $2880 \pm 190$ B.P., may be too recent. A second assay, run on a caribou bone sample taken from the same feature, yielded a date of $3700 \pm 70$ (uncorrected) B.P. Even at an extended temporal span calculated to two standard deviations, the two dates do not overlap statistically. The older of the two estimates is, however, consistent with the dates of 3770 and 3850 B.P. (mean estimates) obtained from two of the other Icebreaker Beach Complex features (Table 2).

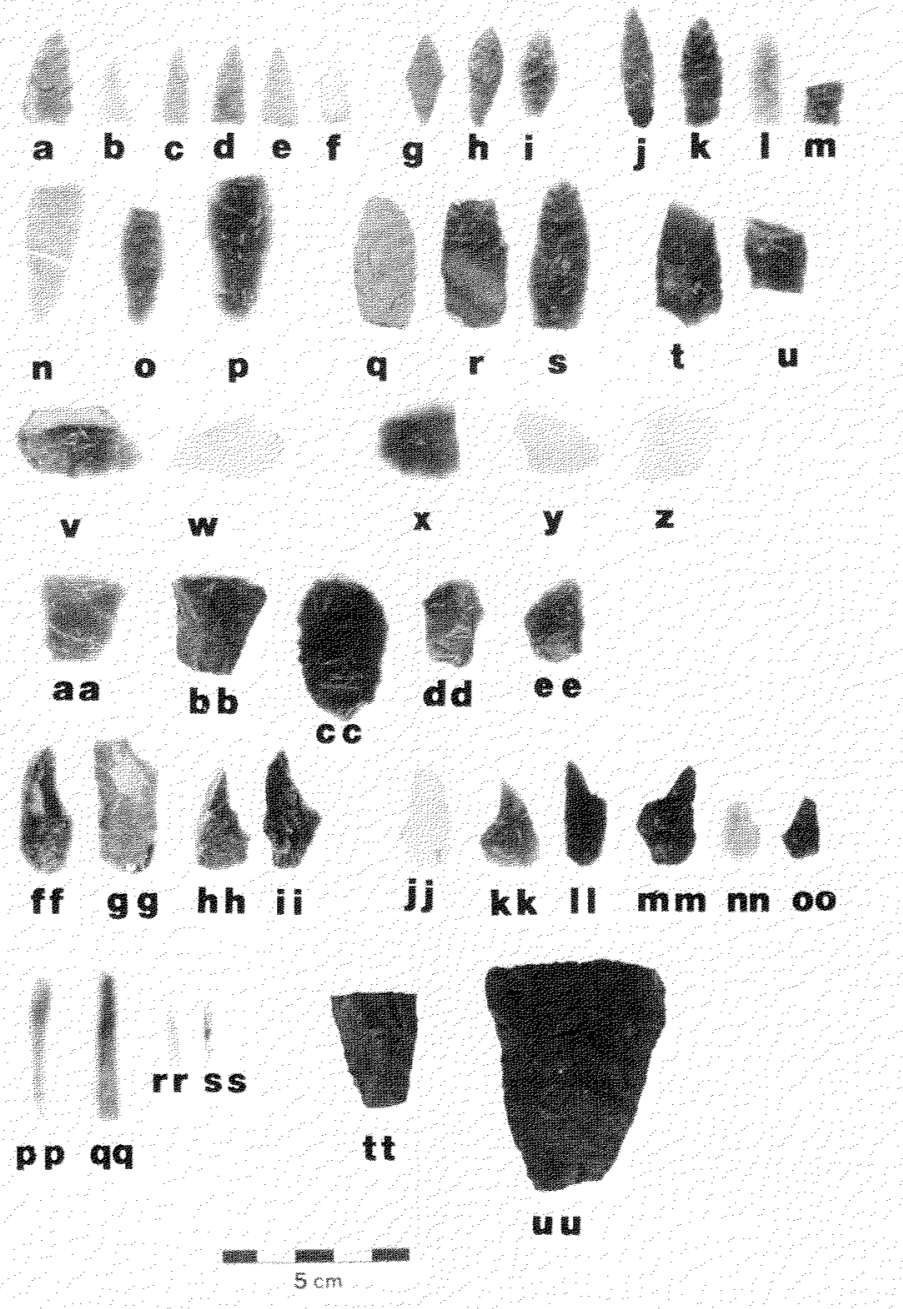

FIG. 7. Selected lithic artefacts from Icebreaker Beach Complex assemblages: a-f) triangular endblades; $g-i$ ) bi-pointed endblades; $j-p$ ) large and small straight or tapered-stem bifaces; q-u) miscellaneous flake knives?; v-z) miscellaneous asymmetric and ovate sideblade fragments; aa-ee) end scrapers; ffii) concave side scrapers; $\mathrm{jj}-\infty$ ) burins; $\mathrm{pp}$-qq) microblades; rr-ss) burin spalls; tt-uu) adze fragments.
Similarly, the date of $c a .4500$ B.P. for the lower end of the Icebreaker Beach temporal range may be too old. This estimate is based on a driftwood charcoal sample recovered from Feature 14 at the Icebreaker Beach Site. A sample of unburned musk-ox bone taken from Feature 4 at the same site yielded a date of $c a .3850$ B.P. This latter value is consistent with the temporal estimates obtained from two other dated Icebreaker Beach Complex features (Table 2). The most plausible explanation for the extreme date from QkHn-13 Feature 14 is that the submitted charcoal sample came from a piece of wood flotsam that had been adrift in the Arctic Ocean for an indeterminate number of centuries prior to being collected and burned (see McGhee and Tuck, 1976, and Arundale, 1981, for discussions of some of the problems associated with arctic driftwood dates).

Rejection of the two extreme dates for the Icebreaker Beach Complex results in a revised temporal range for the Icebreaker Beach Complex of 3850-3700 B.P. (mean estimates).

The cultural/chronological affiliations of the Icebreaker Beach Complex are ambiguous. Several distinctive artefact
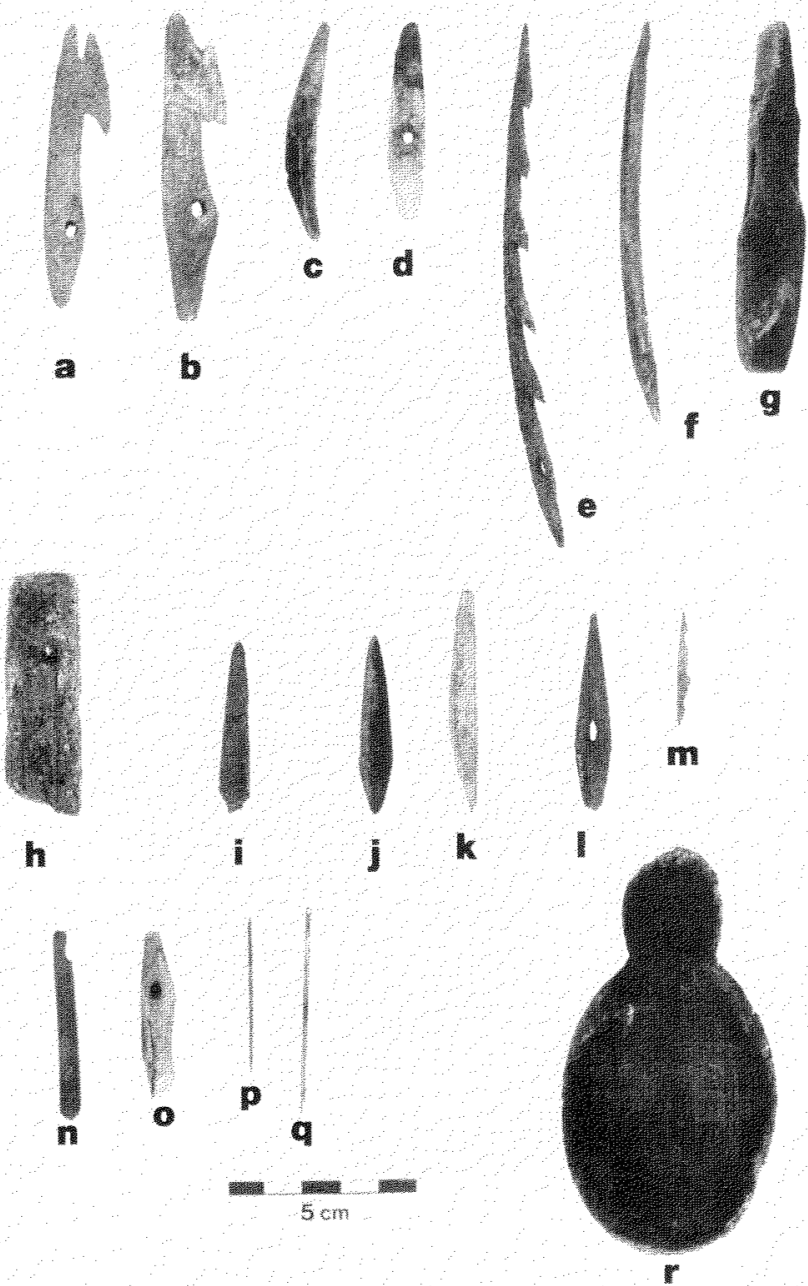

FIG. 8. Selected organic artefacts from Icebreaker Beach Complex assemblages: a-b) tang-based non-toggling harpoon heads; c-d) open-socketed toggling harpoon heads; e) unilaterally barbed fish spear?; f) arrow foreshaft?; $g$ ) possible lance foreshaft; h) throwing board fragment; i) unibarbed dart fragment; j-1) possible harpoon foreshafts; $m$ ) small unilaterally barbed dart; $n-0$ ) worked bone and ivory pieces; p-q) needles; r) bi-lobate whalebone "bowl." 
forms associated with this complex, such as the small bipointed endblades, tapered-stem bifaces, large ovate sideblades and the tang-based, barbed, non-toggling harpoon heads, are considered to be diagnostic of the Independence I Culture (McGhee, 1976, 1979; Maxwell, 1985). Other Icebreaker Beach Complex attributes, including the straightstemmed bifaces, the open-socketed, self-bladed, toggling harpoon heads with single basal spurs and the absence of obvious edge serration on endblades and bifaces, however, are more commonly associated with Early to Middle Pre-Dorset-age assemblages, such as those known from northwest Devon Island (McGhee, 1976, 1979) and the west-central Canadian Arctic (McGhee, 1970, 1976; Taylor, 1967, 1972; MüllerBeck, 1977). These latter assemblages are believed to date to 3700-3300 B.P. (mean age estimates; see Arundale, 1981; Maxwell, 1985).

On the strength of these dual associations, I have argued elsewhere (Helmer, 1984, 1986a, 1988a; see also Bielawski, 1988:68-69) that the Icebreaker Beach Complex represents a transitional stage typologically linking the Independence I and Pre-Dorset occupations of the High Arctic. This interpretation is reinforced by the dates for this complex, which, after rejecting the two extreme values, fall midway between the mean age estimates for the Independence I and Pre-Dorset occupations of the High Arctic (McGhee, 1976, 1979). New data on the Early Saqqaq occupation of West Greenland (Grønnow and Meldgaard, 1988; Grønnow, 1988) and on several Saqqaq-

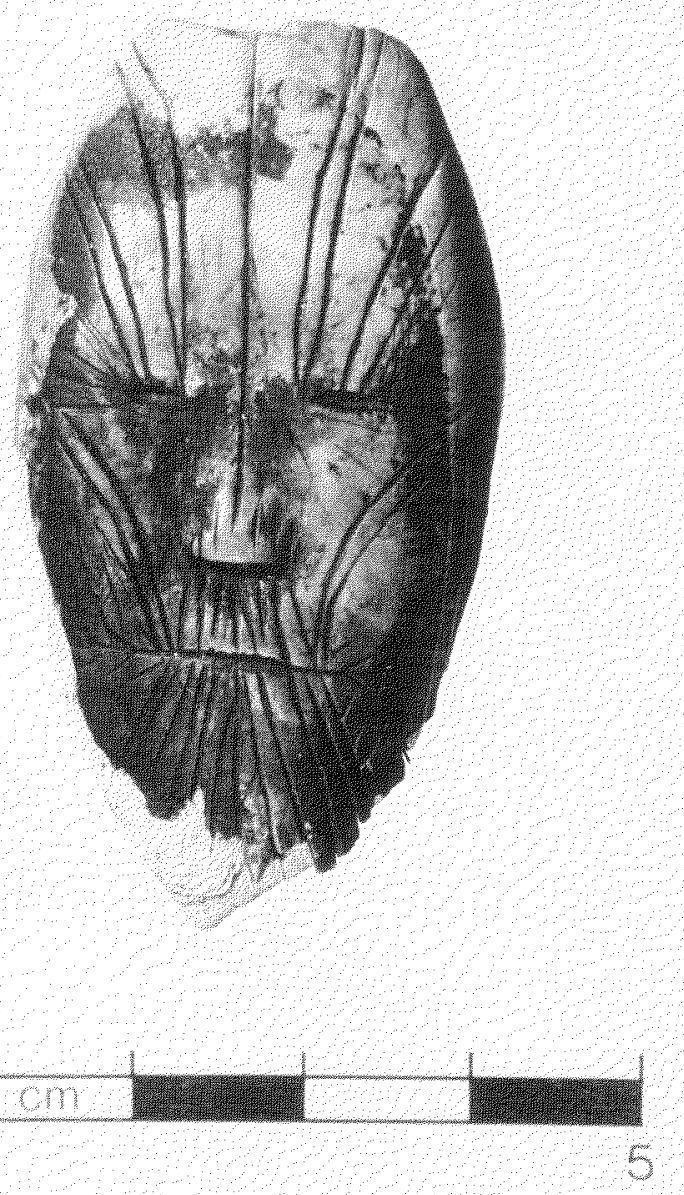

FIG. 9. Anthropomorphic ivory carving from QkHn-13 Feature 1 (Icebreaker Beach Complex). influenced Early Palaeo-Eskimo assemblages from eastern Ellesmere Island (Schledermann, 1990), however, indicate that this interpretation may be too simplistic.

A substantial assemblage of Early Saqqaq lithic and organic artefacts, dating to 3880-3750 B.P. (mean estimates), has recently been recovered from the West Greenlandic site of Qeqertasussuk (Grønnow, 1988; see also Grønnow and Meldgaard, 1988). Although detailed descriptions and illustrations of this material are not yet available, it is clear from preliminary reports that the Qeqertasussuk assemblage bears some striking resemblances to the Icebreaker Beach Complex collections (Grønnow, 1988; Grønnow and Meldgaard, 1988; see also Meldgaard, 1983, for comparable material from the site of Qaja). The most obvious similarities occur in the categories of small contracting-stem, bi-pointed endblades, tapered-stem bifaces, tang-based and barbed non-toggling harpoon heads and self-bladed, open-socketed toggling harpoon heads with single basal spurs. Lacking in the Icebreaker Beach Complex assemblage, however, is any evidence of the distinctive thin, angular burins and the extensive use of grinding and polishing that so strongly characterize many categories of Saqqaq chipped stone tools (Maxwell, 1985).

Similarly, Schledermann (1990:56-90) has recently published detailed descriptions of a series of Saqqaq-influenced assemblages from the Bache Peninsula region of Ellesmere Island. These assemblages date to $3840-3420$ B.P. (mean age estimates). The Ellesmere Island material, particularly the artefacts from the Bight Site (see Schledermann, 1990:86-87), in many ways resemble specific objects in the Icebreaker Beach Complex inventory. Again, what sets the North Devon Lowlands assemblages apart is the absence of the distinctive thin, angular burins and the extensive grinding and polishing of stone tools shared by the Ellesmere and West Greenland Saqqaq-related collections. In particular reference to the discrepancy in burin styles, it is worth noting that Robertson, in his comparative metric analysis of burins from Port Refuge, Ellesmere Island, and the North Devon Lowlands regions, was able to consistently distinguish Schledermann's Saqqaq artefacts from the Icebreaker Beach tools (Robertson, 1989:156).

The Icebreaker Beach Complex, the Early Saqqaq levels at Qeqertassusuk and the Saqqaq-related Bight Site components from the Bache Peninsula clearly have a great deal in common. They all date to $3900-3600$ B.P. They all also share a constellation of features with earlier Independence I components as well as elements that anticipate later technological developments in their respective areas. Obvious stylistic differences, however, set the Icebreaker Beach Complex apart from the two Saqqaq-related industries.

\section{The Twin Ponds Complex}

A Middle Pre-Dorset occupation of the study area, believed to date to 3650-3300 B.P., has been identified at the Twin Ponds Site (QkHn-17), the Field School Site (QkHn-12) and the Icy Bay Site (QkHl-05). This complex may also be represented at Lowther's $(1962,1965)$ Inavik Site (QkHl-01), located on Cape Sparbo. These sites all occur on raised gravel beach terraces ranging in elevation from 4 to $6 \mathrm{~m}$ asl. This occupational episode was first recognized at QkHn-17 and is hence referred to as the Twin Ponds Complex.

The predominant architectural form associated with this complex is a small axial-passage boulder tent ring with a central hearth area (Fig. 10). A variant of this form - a small 
oval boulder tent ring with an upright slab mid-passage arrangement and a central slab-lined box hearth - was found at the Twin Ponds Site.

A total of 1315 identifiable animal bones and bone fragments was obtained from four of the seven excavated Twin Ponds Complex features (McCartney, 1989). These faunal samples exhibit no significant between-feature statistical variation (McCartney, 1989). Small seal bones account for $73.5 \%$ of the combined assemblage. Bird bones, at $9 \%$ of the total, and caribou remains, at $8 \%$, are the next most abundant taxa. Small numbers of whale, walrus, polar bear, bearded seal, musk-ox, large canid (perhaps dog), fox, hare and lemming bones are also represented.

Analysis of seal tooth thin sections indicates that the Twin Ponds Complex features were inhabited between April and February (McCartney, 1989). The main period of use (with minor between-site variations), however, appears to have been between August and December.

A sample of approximately 1670 artefacts, mostly lithic tools, was recovered from the seven excavated Twin Ponds Complex tent rings. A distinguishing feature of this assemblage is the abundance of small, delicately flaked, triangular endblades with concave bases (Fig. 11:a-e). Small straightstemmed and tapered-stem bifaces (Fig. 11:f-l), asymmetric flake knives (Fig. 11:m-p), bi-pointed and ovate sideblades (Fig. 11:q-s), flared and quadrangular end scrapers (Fig. 11: $\mathrm{t}-\mathrm{w}$ ), concave side scrapers (Fig. 11:x-z), a large number of small, very finely made burins - a few of which have been

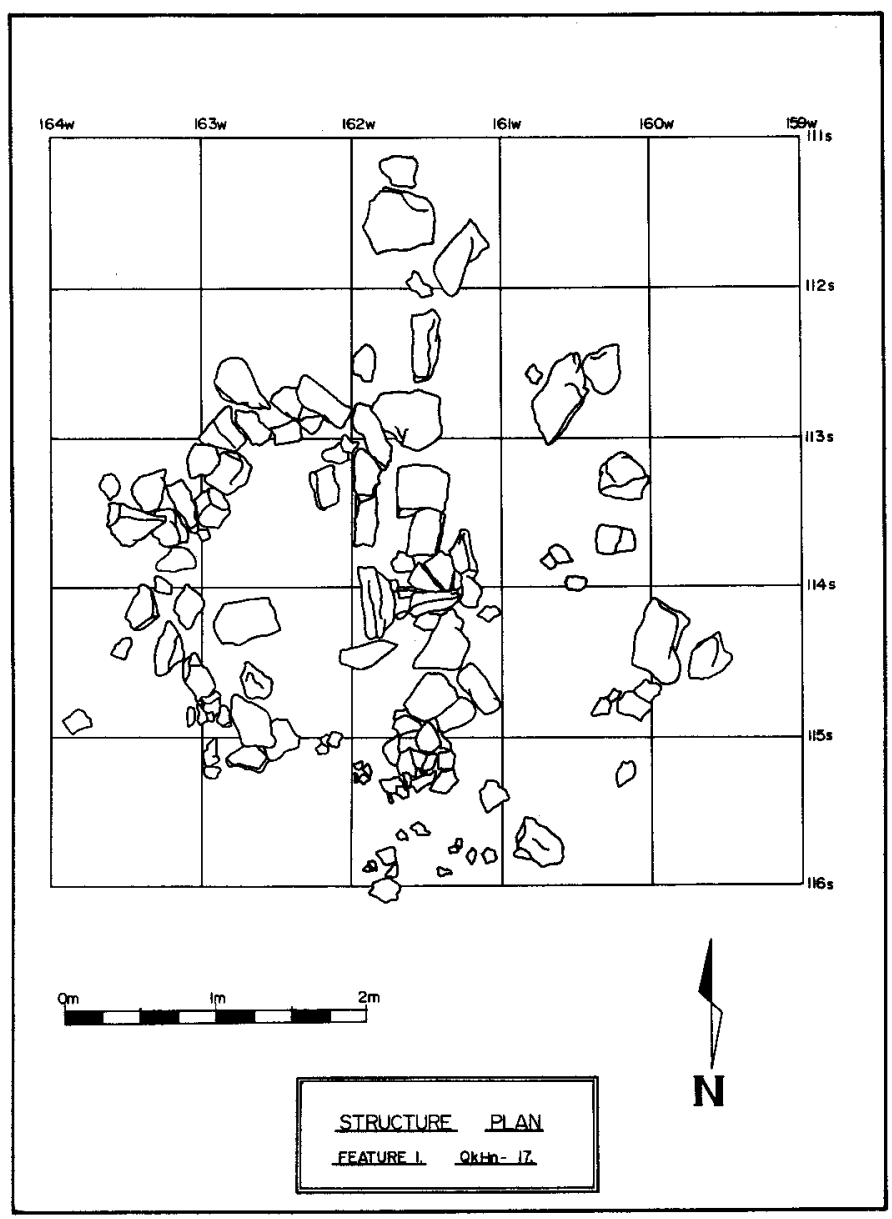

FIG. 10. Plan of QkHn-17 Feature 1 (Twin Ponds Complex). lightly polished (Fig. 11:aa-ii) - and flaked and ground adze blades (Fig. 11:nn) are also common lithic artefact types. In addition, a small conical, self-pointed harpoon head with an open socket and a single basal spur (Fig. 11:0o) and numerous bone needles with very fine, circular eyelets (Fig. 11:pp-qq) have been found in features associated with this complex.

Three radiocarbon dates were obtained from Twin Ponds Complex features (Table 2). Two of these dates, one an extended count assay on a small driftwood charcoal sample from QkHn-17 Feature 1 and the other an Accelerator Mass Spectrometer (AMS) date run on a very small, unidentified wood charcoal fragment from QkHn-12 Feature 6, fall between 3500 and 3700 B.P. (mean estimates).

A third date, run on a small fragment of driftwood charcoal excavated from QkHl-05 Feature 1, yielded a result of $c a$. 4100 B.P. This estimate is several centuries older than dates obtained from presumably older features at the same site located on much higher fossil beaches and is, therefore, considered suspect.

Twin Ponds Complex assemblages share a number of stylistic features in common with artefacts from several western Central Arctic Middle Pre-Dorset components. These include the Umingmak Site (Müller-Beck, 1977) and the Bloody Falls Site (McGhee, 1970). These latter occupations are dated to 3440-3300 B.P. (mean estimates; Arundale, 1981:264).

Similarities between the Twin Ponds Complex and Central Arctic Middle Pre-Dorset assemblages include the presence of small, concave-based, triangular endblades, straight-stemmed endblades and bifaces, bi-pointed sideblades and conical, selfbladed, open-socketed harpoon heads with single basal spurs. The collections from the North Devon Lowlands, however, contain proportionately more microblades, lack extensive polish on burins and do not include the large quartzite tools that characterize the western Central Arctic Pre-Dorset assemblages.

Parallels also exist between the Twin Ponds Complex and the Early/Middle(?) Pre-Dorset Gull Cliff component from Port Refuge on northwestern Devon Island (McGhee, 1976, 1979; Maxwell, 1985). McGhee $(1976,1979)$ has suggested a date of 3700-3500 B.P. for Gull Cliff. Several investigators (Schledermann, pers. comm. 1988; Robertson, 1989; Helmer, 1987b, 1988a), however, have argued that a date of 3500-3300 B.P. for this occupation might be more appropriate.

Attributes shared by these two complexes include taperedstem and straight-stemmed endblades and bifaces, flared end scrapers and various flake knife forms. Gull Cliff, however, lacks the small, concave-based, triangular endblades and conical, open-socketed, toggling harpoon heads found in the North Devon Lowlands components. Conversely, Twin Ponds Complex assemblages lack the triangular sideblades and the barbed and open-socketed harpoon heads found at Port Refuge.

Local comparisons between the Twin Ponds Complex and the slightly older Icebreaker Beach Complex also reveal some very strong similarities. Indeed, in several cases, the degree of typological overlap is so great as to complicate taxonomic placement of some of these assemblages (Helmer, 1986a, 1987b, 1988a). The strength of association between the Twin Ponds and Icebreaker Beach complexes indicates a certain degree of cultural continuity in the North Devon Lowlands sequence between $c a .3900$ and at least 3500 B.P. 


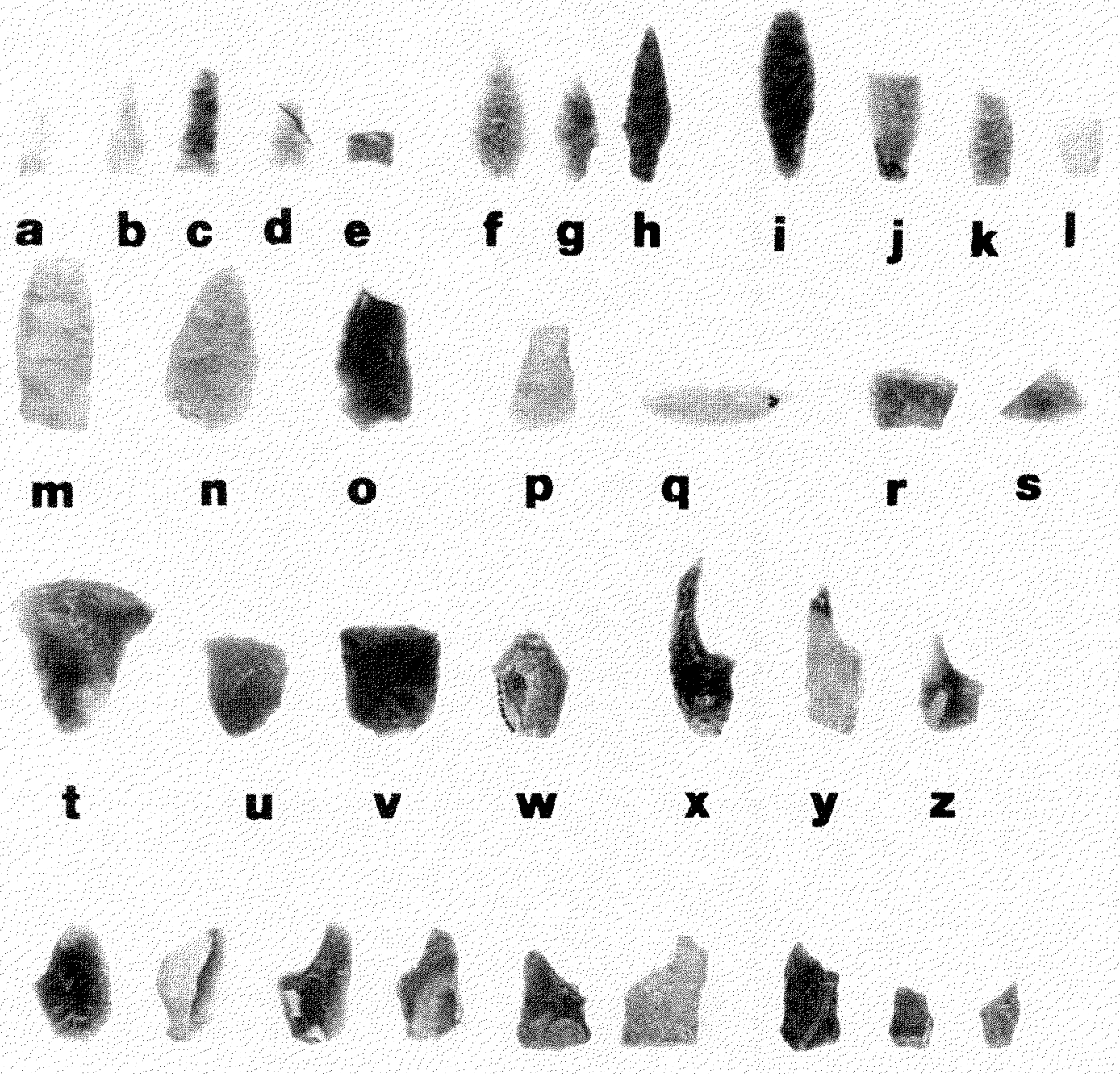

\section{aa bb cc dd ee ff gg hh ii}

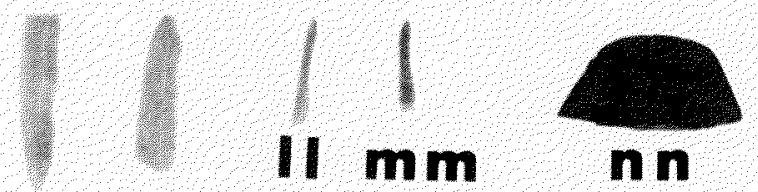

\section{jj $\mathbf{k} \mathbf{k}$}
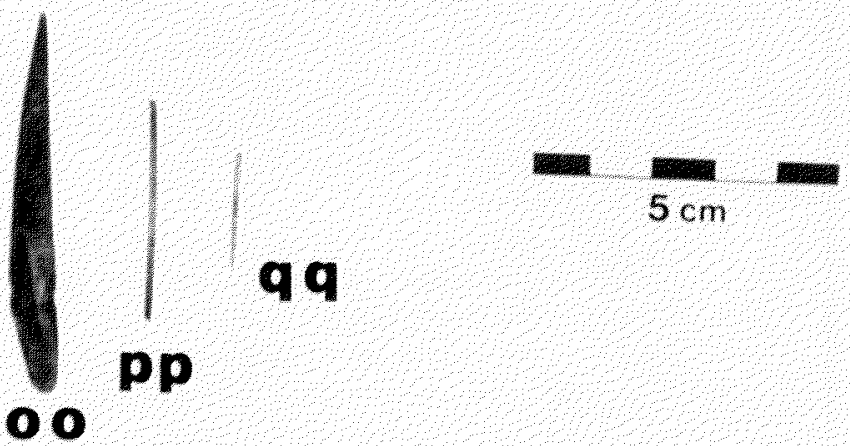

FIG. 11. Selected artefacts from Twin Ponds Complex assemblages: a-e) concave-based triangular endblades; f-1) straight-stem and tapered-stem bifaces; m-p) asymmetric flake knives; $q-s$ ) bi-pointed and ovate sideblades; $t-w$ ) end scrapers; $x-z$ ) concave side scrapers; aa-ii) burins; $j \mathrm{j}-\mathrm{kk}$ ) microblades; $11-\mathrm{mm}$ ) burin spalls; nn) adze fragment; oo) open-socketed toggling harpoon head; $p p-q q)$ needle fragments. 
In contrast to the pattern of extra-regional affiliations exhibited by the Icebreaker Beach Complex, few obvious correspondences can be found between the North Devon Lowlands Middle Pre-Dorset assemblages and the distinctive, contemporaneous Middle Saqqaq and Saqqaq-related industries of West Greenland and eastern Ellesmere Island (Maxwell, 1985; Schledermann, 1990). This suggests that interactions between the North Devon Lowlands and areas within the Saqqaq sphere of influence may have been severed or severely curtailed at some time shortly after $\mathrm{ca} .3700$ B.P.

\section{The Rocky Point Complex}

Evidence of a fourth Early Palaeo-Eskimo occupation of the study area, possibly dating to $3200-2800$ B.P., was found at the Rocky Point Site (QkHn-27). A related component may also occur at the Field School Site (QkHn-12), but this remains unsubstantiated. This occupational episode, best represented at $\mathrm{QkHn}-27$, is referred to as the Rocky Point Complex.

Thirteen habitation features (not necessarily all occupied at the same time) were found at the Rocky Point Site. They are distributed along a long linear gravel ridge situated approximately $7 \mathrm{~m}$ asl. These features are generally small, amorphous, oval tent ring outlines (Fig. 12). Several of the rings show signs of post-occupational disturbance. No obvious hearths were found in any of these structures.

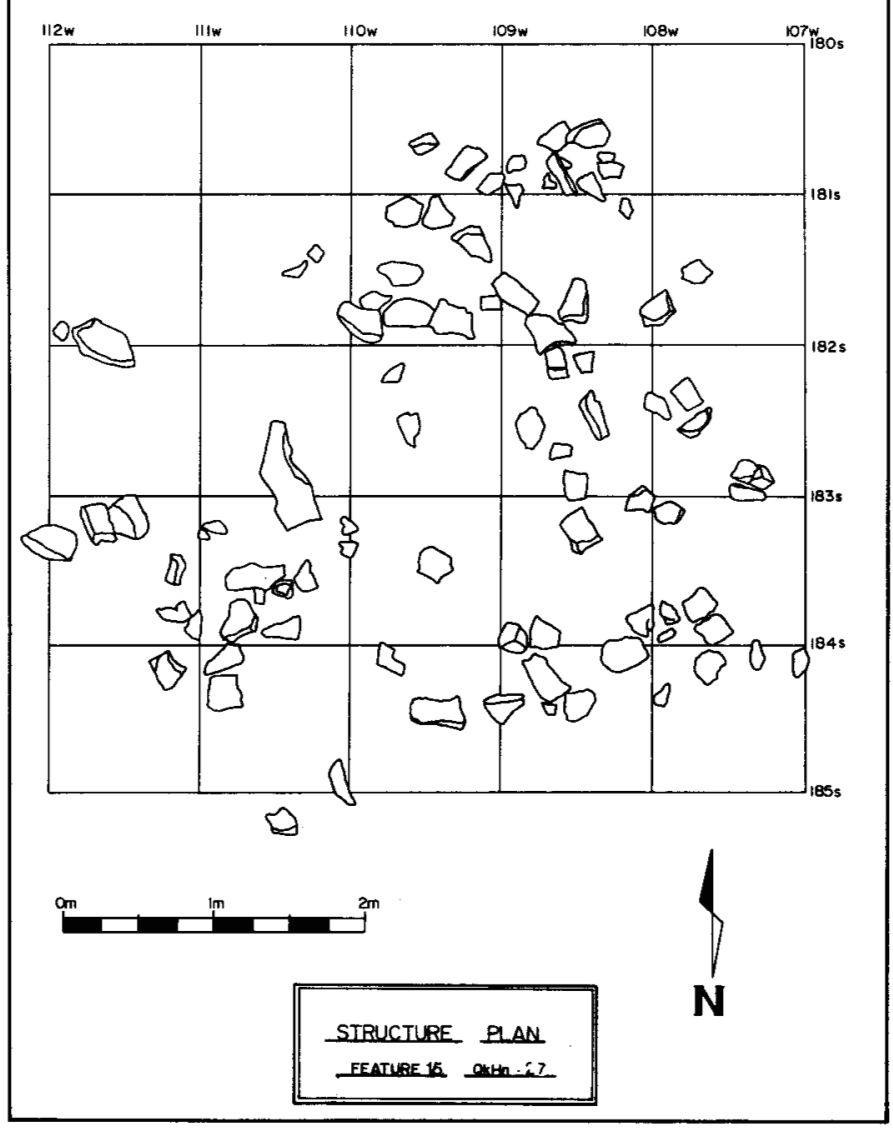

FIG. 12. Plan of QkHn-27 Feature 15 (Rocky Point Complex).
Two complete tent rings were excavated at QkHn-27. A small faunal assemblage of 357 identifiable bone fragments was recovered from one of these (QkHn-27 Feature 17). Small seal bones constitute $76.75 \%$ of this collection (McCartney, 1989). Birds (including nesting waterfowl and shorebirds) at $11 \%$, walrus at $3.4 \%$ and fox at $3.0 \%$ of the total are the next most abundantly represented taxa. Whale, polar bear, bearded seal, caribou, large canid and lemming bones have also been identified in the collection.

Feature 17 at QkHn-27 also yielded the nearly complete skeleton of a fetal (7-12 weeks premature) human infant (Helmer and Kennedy, 1986). The infant is thought not to have been formally interred. Very few examples of Early Palaeo-Eskimo human remains have ever been found in the Eastern Arctic (see Grønnow, 1988:27). Unfortunately, being fetal, the Rocky Point skeleton tells us little about the biological affinities of Early Palaeo-Eskimo peoples (Helmer and Kennedy, 1986).

No seal canine teeth suitable for thin sectioning were obtained from Feature 17 at $\mathrm{QkHn}-27$. The only direct indicators of seasonality for this complex, therefore, are the bones of migratory birds that occur in relative abundance in the faunal assemblage. These suggest that the Rocky Point Site was probably occupied sometime between April and September.

This estimate of seasonality is indirectly corroborated by Hanna's (1989) recent study of the weight-loading patterns of the boulders used to build the Palaeo-Eskimo tent rings in the North Devon Lowlands. One of the premises underlying Hanna's study is that skin tents would, as a rule, have been weighted more heavily on the side, or sides, facing the strongest prevailing winds. The patterns observed for the Rocky Point Site tent rings are consistent with the loadings expected to accommodate the prevailing winds at this location during the summer months.

The small assemblage of artefacts $(\mathrm{N}=380)$ recovered from the two fully excavated Rocky Point Complex habitation features exhibits some qualitative between-feature differences. The artefact sample from QkHn-27 Feature $15(\mathrm{~N}=210)$ includes several small triangular endblades with straight bases (Fig. 13:a,d), two broadly side-notched biface fragments (Fig. 13:e-f), a stemmed end scraper (Fig. 13:k), two fragmentary ground burins (Fig. 13:1-m) and a large number of relatively narrow microblades (Fig. 13:hh-ii). The most distinctive feature of this assemblage, however, is the preponderance of small laterally notched burins (Fig. 13:n-aa). Three open-socketed harpoon heads with endblade inset slots and transverse line holes (Fig. 13:ijj-11) and several needles with ovate crosssections and circular drilled eyelets were also found.

Feature 17 yielded a slightly smaller collection of artefacts $(\mathrm{N}=170)$. This assemblage includes a large straight-stemmed biface (Fig. 14:b), a small concave side scraper (Fig. 14:g), several unnotched burins (Fig. 14:h-j), a few microblade fragments (Fig. 14:m-n) and a very unusual harpoon head (Fig. 14:o). This latter object has an endblade inset slot, a single line hole, an open socket on the dorsal surface, a corresponding deep socket-like groove on the ventral surface and four basal spurs.

The differences between these assemblages may simply be a function of sampling error. Conversely, they may indicate separate periods of occupation at the Rocky Point Site. It should be noted, however, that several artefact fragments from the two features have been cross-fitted. This suggests that the rings may have been contemporaneous. 
Two radiocarbon dates have been obtained for the Rocky Point Site (Table 2). These include a conventional date on a probable arctic willow charcoal sample from Feature 17 and an AMS date on a very small unidentified wood carbon sample taken from the interior of Feature 15. The two dates fall between 3800 and 4100 B.P. (mean estimates). Despite their internal consistency, these dates may not reflect the true age of the Rocky Point Complex.

In the comparative analysis of the Rocky Point Complex assemblage, no close similarities with collections from elsewhere in the Eastern Arctic dating to the period 4100-3800 B.P. were found. Strong parallels, on the other hand, were noted between the North Devon Lowlands material and assemblages reported from the Ridge, Rastodden and Jaeger sites on eastern Ellesmere Island (Schledermann, 1978a, 1987, 1990; Schledermann and McCullough, 1988b), the Sea Horse Gully Site on southwestern Hudson Bay (Meyer, 1977) and the Nukasusutok-2 and Okak-4 sites from northern Labrador (Cox, 1978). These latter sites have all been dated to the period 3000-2800 B.P. (mean estimates) and are considered to
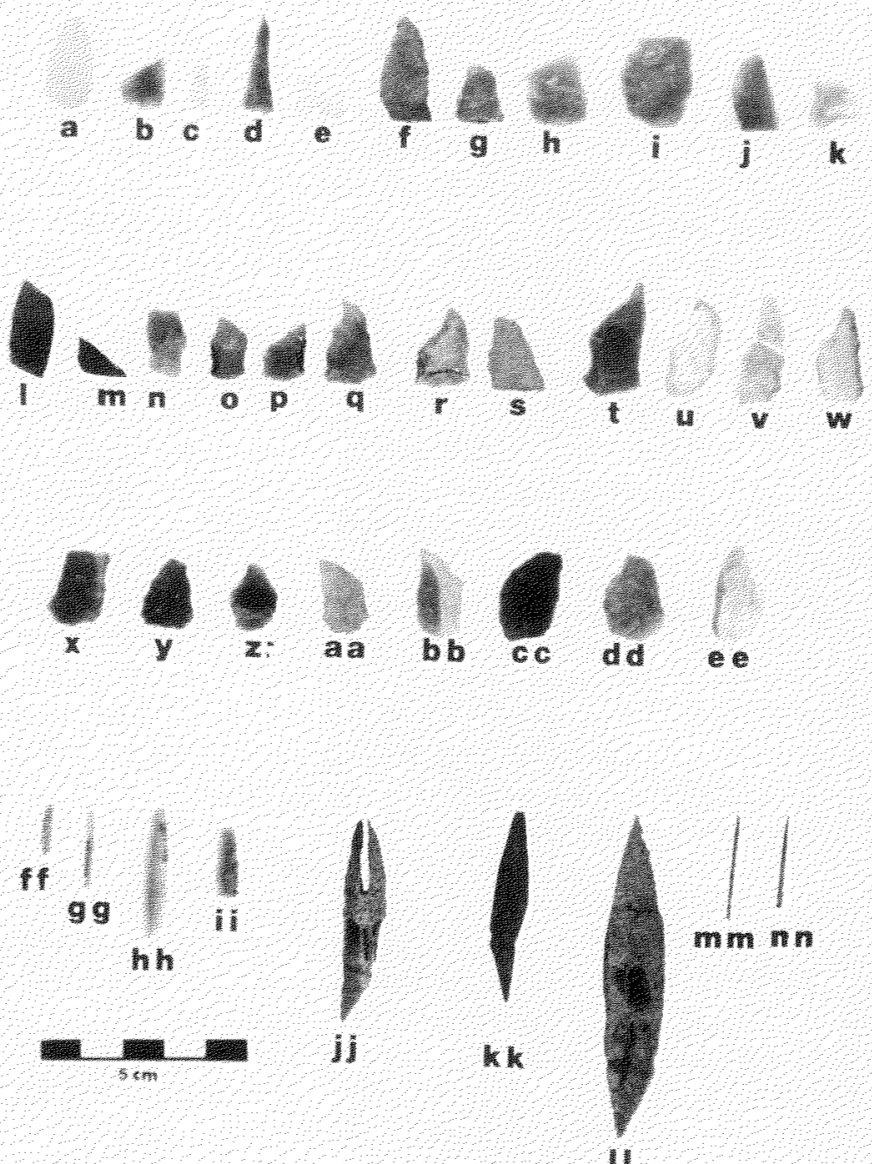

FIG. 13. Selected artefacts from QkHn-27 Feature 15: a,d) triangular endblade fragments; b-c) miscellaneous endblade fragments; e-f) side-notched biface fragments; g-j) miscellaneous biface fragments; $k$ ) end scraper; $1-m$ ) ground burin? fragments; $n$-aa) laterally notched burins; bb-ee) burins; ff-gg) burin spalls; hh-ii) microblade fragments; $\mathrm{jj}$-11) open-socketed harpoon heads with transverse line holes; mm-nn) needle fragments.
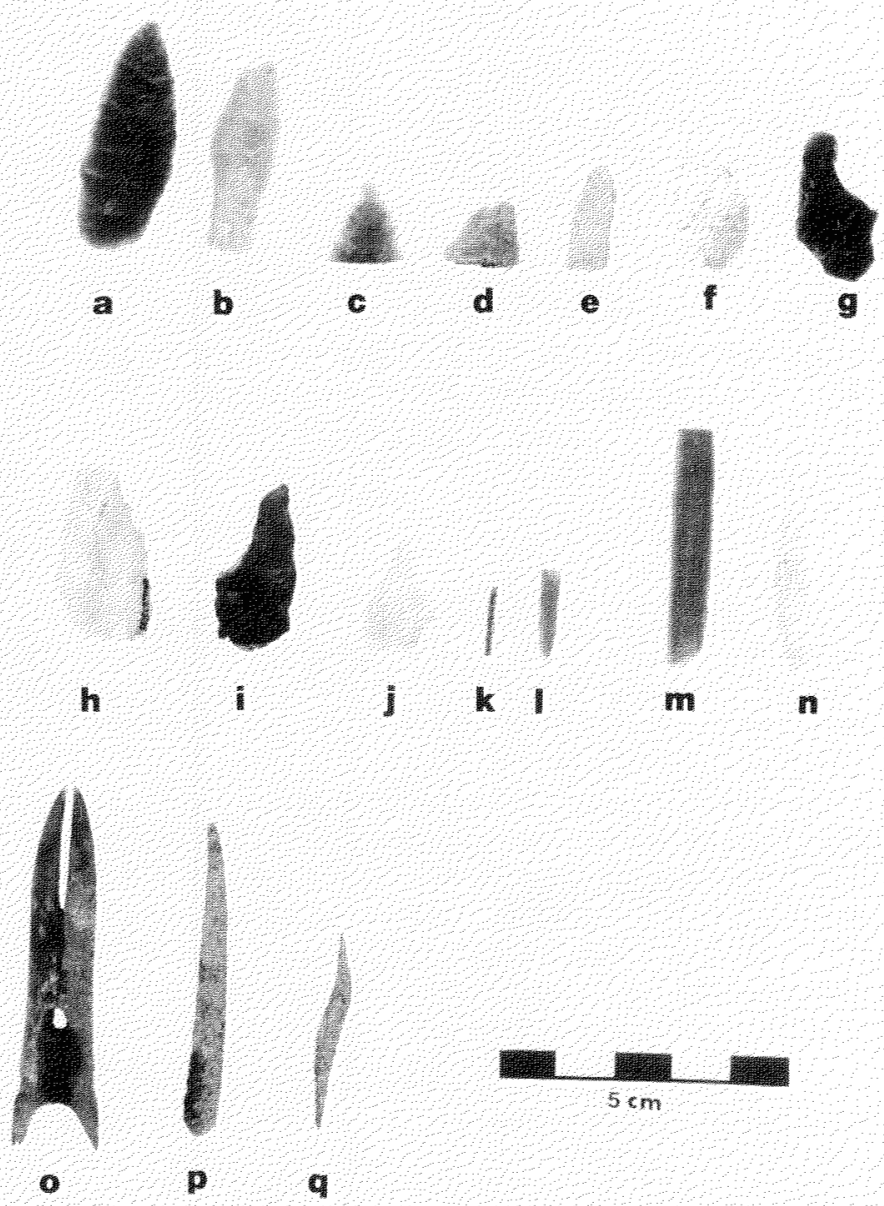

FIG. 14. Selected artefacts from QkHn-27 Feature 17: a) biface; b) stemmed biface; $c-e)$ miscellaneous biface fragments; $f-g$ ) concave side scrapers; $h-j$ ) burins; $k-1$ ) burin spalls; $m-n$ ) microblades; o) open-socketed harpoon head with four basal spurs; $p-q$ ) unidentified bone/antler artefact fragments.

represent very Late Pre-Dorset occupations. Specific attributes shared by the Rocky Point Complex and these "terminal" PreDorset components include broadly side-notched bifaces or endblades, a small number of polished burins and, most particularly, the distinctive small laterally notched burins noted earlier.

The comparative evidence indicating that the Rocky Point Complex represents a Late Pre-Dorset occupation dating to 3000-2800 B.P. is more compelling than the two radiocarbon dates of ca. 4000 and 3800 B.P. The reasons for the major discrepancy between radiometric and typological age estimates for this complex are not known. The presence of multiple occupations at the site cannot, of course, be ruled out as an alternate explanation.

Within the study area, there is only limited evidence linking the Rocky Point Complex to the earlier Twin Ponds Complex. The best indication of an association is provided by a number of burins found in the Twin Ponds Complex assemblage that appear to anticipate the distinctive laterally notched forms associated with the Rocky Point Site features (e.g., Fig. 11:ee$\mathrm{gg}$ ). From the rather tenuous nature of this link it appears that a gap of several centuries separates the Middle Pre-Dorset and Late Pre-Dorset occupations of the study area. 


\section{THE LATE PALAEO-ESKIMO OCCUPATIONS} OF THE NORTH DEVON LOWLANDS

\section{The Cape Hardy Complex}

Evidence of an early and rather limited Late Palaeo-Eskimo occupation of the North Devon Lowlands was recovered from three small sites in the study area. These are the Cape Hardy Site (QkHl-04), the Tote Road Site (QkHn-37) and the Skogn Site (QkHm-14). All three sites are situated on raised gravel beaches at approximately $2-4 \mathrm{~m}$ asl. This complex was first identified at QkHI-04, hence its designation as the Cape Hardy Complex.

No readily identifiable surface habitation features could be seen at any of the three sites. Test excavations at QkHn-37, however, revealed a $c a .2 .5 \mathrm{~m}$ long by $0.5 \mathrm{~m}$ wide buried pavement of horizontally laid dolomite slabs surrounded by an amorphous sub-rectangular arrangement of small boulders (Fig. 15). In addition, part of a buried mid-passage structure comprised of thin vertically embedded dolomite slabs set $c a$. $0.5 \mathrm{~m}$ apart was uncovered at the Skogn Site.

The absence of well-preserved faunal remains at any of the excavated Cape Hardy Complex sites combined with a lack of ancillary seasonal data (such as boulder weight-loading figures for individual habitation features) unfortunately precludes even a general estimate of seasonality for the features associated with this complex.

The small assemblage of artefacts (numbering no more than 60 artefacts) recovered from the tested and/or surface-collected Cape Hardy Complex sites is characterized by a variety of large side-notched bifaces (Fig. 16:a-d,u-w), wide triangular endblades with straight bases (Fig. 16:f-h), an assortment of biface forms (Fig. 16:e,y-z), large ovate sideblades (Fig.

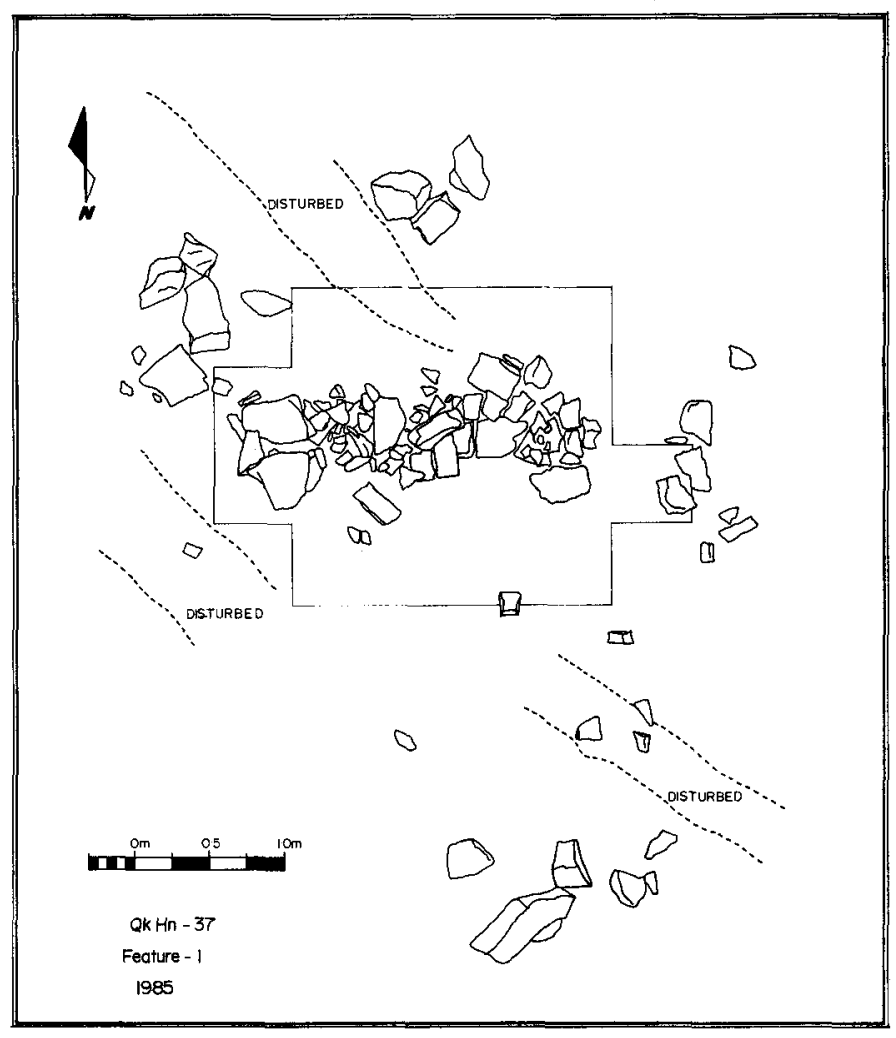

FIG. 15. Plan of QkHn-37 Feature 1 (Cape Hardy Complex). 16:k-1), small thumbnail end scrapers (Fig. 16:i), large, broadly side-notched, flaked and ground burins (Fig. 16: $\mathrm{m}-\mathrm{o}, \mathrm{aa}$ ), burin spalls (Fig. 16:r-s) and a number of very narrow microblades (Fig. 16:p-q,cc). A small fragment of a ground and polished adze blade (Fig. 16:t) and a small piece of a round soapstone lamp (Fig. 16:dd) were also found in association with the features assigned to this complex.

The Cape Hardy Complex assemblages share a number of key attributes in common with Independence II components reported from northeast Greenland (Knuth, 1967, 1968, 1977/78) and northwestern Devon Island (McGhee, 1976, 1979) and with early Groswater Dorset components known from Newfoundland and Labrador (Fitzhugh, 1972, 1976; Cox, 1978). They are also comparable to the "Transitional Stage" assemblages recently reported by Schledermann (1978a, 1987, 1990; Schledermann and McCullough, 1988a,b; McCullough and Schledermann, 1989) from the Bache Peninsula area of eastern Ellesmere Island.

The principal attributes shared by the Cape Hardy Complex and these regionally disparate cultural manifestations include broadly side-notched bifaces, distinctive side-notched flaked and ground burins, large ovate sideblades, ground adzes and, in several instances, axial mid-passage habitation features. Unfortunately, more specific comparisons cannot be made due to the extremely small size of the artefact assemblages from the North Devon Lowlands.

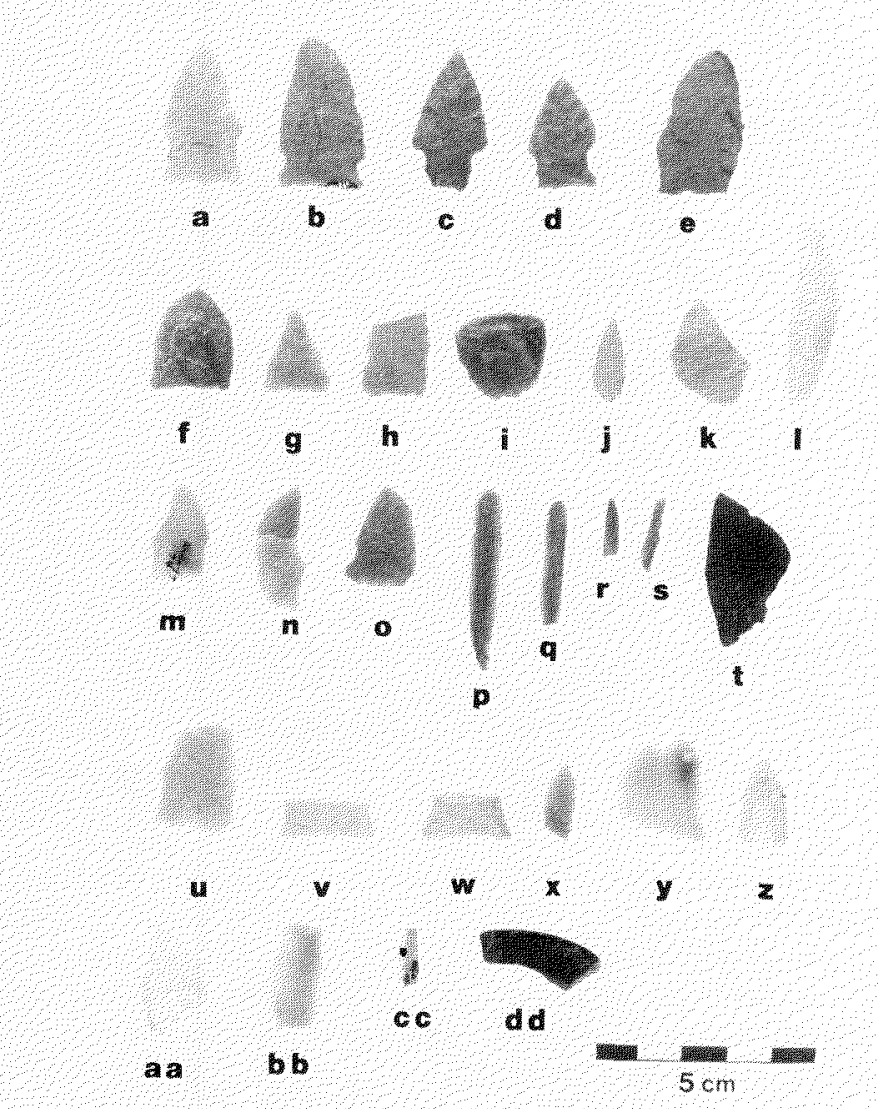

FIG. 16. Selected artefacts from Cape Hardy Complex assemblages (Note: a-t from QkHn-37, u-dd from QkHI-4): a-d) side-notched bifaces; e) miscellaneous biface; $f-h$ ) triangular endblades; i) end scraper; $j-1)$ sideblades?; $m-n$ ) spalled and ground burins; $p-q$ ) microblades; $r-s$ ) burin spalls; $t$ ) adze fragment; $u-w)$ side-notched biface fragments; $x-z$ ) miscellaneous biface fragments; aa) spalled and ground burin; bb) blade fragment; cc) microblade fragment; dd) lamp fragment. 
Independence II and early Groswater Dorset components have been radiocarbon dated to the period 3100-2600 B.P. (mean estimates; see Arundale, 1981; Cox, 1978). Similar dates are believed to apply to the Ellesmere Island components (Schledermann, 1990:325-326). A sample of driftwood charcoal found beneath the central pavement in Feature 1 at the Cape Hardy Complex Tote Road Site yielded a date of $c a$. 2700 B.P. (mean estimate), which is consistent with these age estimates (Table 2).

Collectively, Independence II, Groswater Dorset and Schledermann's Transition Period (along with Meldgaard's [1960] Dorset I phase at Igloolik) constitute regional expressions of what Maxwell (1985:121-123) has termed the "PreDorset to Dorset Transition." According to Maxwell (1985:122), this transitional period reflects the dynamic and complex technological, economic and social changes in Early Palaeo-Eskimo lifeways that led, ultimately, to the emergence of the distinctive Late Palaeo-Eskimo Dorset cultural pattern.

The Late Pre-Dorset Rocky Point Complex may actually represent the first phase of the Pre-Dorset to Dorset transition in the North Devon Lowlands sequence. Certainly Rocky Point Complex assemblages contain traits, such as partially ground burins and very broadly side-notched bifaces, that seem to anticipate later typological developments seen in the Cape Hardy Complex components. Given the limited number of sites and the very small assemblages characterizing both occupational episodes, however, in situ continuity between the Rocky Point and Cape Hardy Complexes is unlikely.

\section{The Lethbridge Complex}

The final Palaeo-Eskimo occupation of the North Devon Lowlands is represented by very limited data recovered from three multi-component sites in the study area, the Cook Site (QkHl-02), the Carswell Site (QkHl-3) and the Field School Site (QkHn-12). The small number and generally "impoverished" nature of the Late Palaeo-Eskimo components at these three sites suggests that the North Devon Lowlands were neither extensively nor intensively exploited during this occupational episode. In deference to the pioneering work done by the archaeologist T.C. Lethbridge (1939) at the Cook Site, the sixth Palaeo-Eskimo occupation of the North Devon Lowlands has been named the Lethbridge Complex.

No obvious Palaeo-Eskimo architectural features survive at the Cook or the Field School sites. The relevant components at both are represented solely by small assemblages of Late Palaeo-Eskimo artefacts found in the walls and floors of excavated Thule Culture winter houses (Lethbridge, 1939; Park, 1986).

Two boulder "longhouse" structures measuring approximately $15-20 \mathrm{~m}$ in length by $4 \mathrm{~m}$ in width were, however, discovered at the Carswell Site (Lowther, 1965; Helmer, 1988b). At least one external hearth row feature occurs in association with these communal structures. Longhouse features and hearth rows, similar to those from the Carswell Site, have been reported from northern Ungava (Plumet, 1969, 1985), Victoria Island (Taylor, 1972), Bathurst Island (McGhee, 1981; Helmer, 1981), Ellesmere Island (Schledermann, 1978a, 1987, 1990) and Somerset Island (Damkjar, pers. comm. 1987). According to Schledermann (pers. comm. 1990), such structures also occur in northwestern Greenland.
No faunal data were recovered from any of the Lethbridge Complex sites examined. As a result, the seasonality of these components cannot be adequately assessed.

Of the three Lethbridge Complex sites, only the Cook Site has been excavated (Lethbridge, 1939; Helmer, 1986b). A modest collection of lithic and organic tools was recovered from this site by T.C. Lethbridge in 1936 (Lethbridge, 1939). This assemblage, which occurred in a mixed context with Thule Culture materials, includes a number of side-notched bifaces and asymmetric knives, a ground burin, a Dorset Parallel harpoon head, an antler box bottom, several ivory spatulate tools with incised X-ray skeletal motifs and an incised wood piece that may be a kayak representation (Lethbridge, 1939:209,213,215).

In an effort to define more precisely the Palaeo-Eskimo component at the Cook Site, limited test excavations were undertaken in 1985 in what was thought to be a Late PalaeoEskimo semi-subterranean house depression (Helmer, 1986b). Unfortunately, only a modest, largely undiagnostic lithic artefact assemblage was recovered. The feature itself is now believed to have been a pit from which the later Thule inhabitants of the site excavated sod blocks with which to roof their winter houses (Helmer, 1986b).

The only other Lethbridge Complex artefacts found in the study area are a small ivory carving of a squatting(?) human figure discovered by Park (1986) in the wall fill of a Thule winter house at QkHn-12 and a badly decomposed Dorset Parallel harpoon head found (but left in situ) in the interior of one of the longhouse features at the Carswell Site.

No radiocarbon dates were obtained from any of the components associated with this occupational episode.

Lethbridge Complex artefacts, as few as they are, find striking parallels in Late Dorset period assemblages found throughout the Eastern Arctic (see Maxwell, 1985, for an excellent summary of known Late Dorset sites and assemblage characteristics). The best indicators of a Late Dorset affiliation for the Lethbridge Complex are the Dorset Parallel harpoon heads reported from the Cook and Carswell sites, the ivory spatulate pieces with X-ray motifs from the Cook Site and the human figure from the Field School Site.

Chronological estimates falling between 1500 and 1000 to 500 (depending on location) years B.P. have been obtained from the relatively few radiocarbon-dated Eastern Arctic Late Dorset components (see Helmer, 1981:165-171; Maxwell, 1985:218). A similar temporal range likely applies to the Late Dorset occupation of the North Devon Lowlands.

Despite a concerted survey effort, no evidence of an Early Dorset (ca. 2600-2000 B.P.) or a Middle Dorset (ca. 20001500 B.P.) occupation of the North Devon Lowlands has been found. From this it must be concluded that the study area was abandoned for as long as 1700 years following the Transitional Period Cape Hardy Complex occupation at ca. 2700 B.P.

A similar pattern of local disjuncture in the Late PalaeoEskimo occupational sequence occurs elsewhere in the Canadian High Arctic. At Port Refuge on northwestern Devon Island, for example, a Transitional Period Independence II occupation is followed by a Late Dorset occupation after a hiatus of approximately 1500-2000 years (McGhee, 1976, 1981). In a slightly different sequence of events, a Transitional Period Dorset occupation in the McDougall Sound region, 
possibly dating to $c a .3000$ B.P., is followed by an Early Dorset occupation that has been radiocarbon dated to 25002200 B.P. (mean estimates; see Helmer, 1980, 1981). After 2200 B.P., no further evidence of human habitation occurs in this area until the arrival of Late Dorset peoples at $c a$. 15001000 B.P. This latter scenario also applies to the Bache Peninsula region of Ellesmere Island (Schledermann, 1987, 1990).

It is clear that major population disruptions were occurring in the Canadian High Arctic beginning with the Transitional Period. Settlement intensity began to decline in many areas as early as Late Pre-Dorset times. This trend continued throughout the Transitional Dorset Period (except, it seems, in the Bache Peninsula region [Schledermann, 1990:167]). Eventually, locales such as the North Devon Lowlands and the Port Refuge area were abandoned altogether. In some areas, such as the McDougall Sound and Bache Peninsula regions, settlement persisted for several more centuries, as evidenced by the limited occurrence of an Early Dorset occupation in these locales. But, here too, occupation eventually came to an abrupt end.

After a hiatus of up to two millennia, all the preceding High Arctic locales, including the North Devon Lowlands, were reoccupied by a people bearing a uniform technology, sharing a common ideology (as evinced by a highly developed artistic tradition expressed in symbolically decorated ivory, antler, wood and bone objects) and possibly practicing distinctively different settlement and subsistence strategies from their acknowledged forebears (Helmer, in press; Maxwell, 1985; McGhee, 1981; Schledermann, 1990). This reoccupation of the Far North by Late Dorset peoples was to prove short lived, however, as the first groups of Thule Culture whale hunters who were to eventually replace and/or assimilate the Dorset Culture - began to arrive in the High Arctic Islands by as early as ca. 1000 B.P. (Maxwell, 1985:252-261).

\section{DISCUSSION: IMPLICATIONS OF THE NORTH DEVON LOWLAND \\ PALAEO-ESKIMO SEQUENCE FOR HIGH ARCTIC PREHISTORY}

The question of occupational continuity in the High Arctic Palaeo-Eskimo cultural sequence has long been the subject of debate among arctic researchers (Helmer, 1980; Maxwell, 1985; McGhee, 1976, 1979; Schledermann, 1978b, 1990). Based on his pioneering work at Port Refuge on northwestern Devon Island, McGhee (1976) concluded that the Arctic Archipelago was cyclically occupied and abandoned (often for extended periods) by small, widely dispersed bands of PalaeoEskimo hunters. In opposition to this interpretation, Schledermann (1978b), supported by Helmer (1980, 1981), presented data from the Crozier Strait and McDougall Sound areas of the central High Arctic that indicated far greater cultural continuity in the far northern Palaeo-Eskimo occupational sequence.

Recently, however, Schledermann (1990:314) has pointed out the basic fallacy (common to both interpretations) of extrapolating broad regional demographic patterns from spatially restricted local sequences. In his synthesis of the PalaeoEskimo prehistory of the Bache Peninsula region of eastern Ellesmere Island (an area that boasts an impressive record of human habitation spanning $c a .4500$ years), Schledermann (1990) demonstrates a local cultural sequence characterized by wide fluctuations in occupational intensity. His reconstruction recognizes periods of sporadic human activity, episodes of extensive occupation, perhaps by a resident population, and at least one extended period of total abandonment of the area.

The sequence of Palaeo-Eskimo occupations in the North Devon Lowlands shows a comparable pattern of fluctuating occupational intensity. During the initial period of occupation (associated with the Far Site Complex), the study area appears to have only been used sporadically by comparatively small groups. The next two occupational episodes, however, were far more extensive and intensive. Sites associated with the Icebreaker Beach and Twin Ponds complexes are more numerous, contain more habitation features and yield larger artefact and faunal assemblages than earlier sites. Clearly, this was a major period of cultural activity in the study area. With the subsequent Late Pre-Dorset Rocky Point Complex, occupational intensity in the North Devon Lowlands declined sharply. This downward trend continued during the Transitional Dorset Cape Hardy Complex - an interesting contrast to the Bache Peninsula area, where this time frame marks a period of heightened activity (Schledermann, 1990). Finally, the North Devon Lowlands were abandoned altogether until Late Dorset times, when groups associated with the Lethbridge Complex returned to make sporadic use of the study area.

It has been argued elsewhere (McCartney and Helmer, 1989; McCartney, 1989) that the acknowledged sensitivity of High Arctic terrestrial mammal populations (musk-ox and caribou) to overpredation may have been a major contributing factor to the periodic use and abandonment of the North Devon Lowlands. Local herds of musk-ox and caribou in study area - sources of important raw materials (such as furs, antler. and bone) crucial for survival in the Far North - were likely never large enough to support long-term exploitation. Recognizing this, McCartney (1989) has suggested that Early Palaeo-Eskimo hunters in the North Devon Lowlands and, by extension, perhaps elsewhere in the High Arctic were obliged to practice a highly mobile subsistence/settlement strategy based on the periodic short-term exploitation of specific local areas that had to be abandoned once resident terrestrial mammal populations fell below critical levels.

It is conceivable, given current interpretations of huntergatherer adaptive behaviour (e.g., Winterhalder and Smith, 1981), that specific localities with a suitable mix of available terrestrial and sea mammal resources were well known to High Arctic-adapted Early Palaeo-Eskimo peoples. These areas would have been regularly "monitored" by hunters to assess the relative status of their terrestrial mammal resources. Decisions to abandon one area and move to another (either en masse or more slowly, by attrition) would have been based on these assessments. The high degree of settlement mobility implied in this interpretation provides one plausible explanation for both the rapid and far-reaching dissemination of stylistic traits that characterize Palaeo-Eskimo prehistory and the observed patterns of inter-regional stylistic variations in High Arctic Palaeo-Eskimo material culture to be discussed below.

It is becoming increasingly clear that no one local area in the Arctic Archipelago is likely to yield a record of continuous occupation by Palaeo-Eskimo hunters. Viewed from a broad regional perspective (i.e., combining data from the Bache Peninsula, the North Devon Lowlands, Port Refuge, the Crozier Strait/McDougall Sound area and elsewhere), however, it may be possible to argue for a virtually continuous 
human presence (albeit of varying intensity) in the High Arctic as a whole between $\mathrm{ca} .4500$ B.P. and perhaps 2200 B.P, the latter date referring to the estimated termination of the Late Palaeo-Eskimo Early Dorset phase. Still, it must be noted that no reliable evidence of a Middle Dorset presence (dating from ca. 2000 B.P. to 1500 B.P.) has so far been found at any locality in the Arctic Archipelago. Extending the case for occupational continuity in the High Arctic to embrace the entire Palaeo-Eskimo Tradition cannot, therefore, be supported.

Current interpretations of the cultural historical dynamics of High Arctic Palaeo-Eskimo prehistory are also challenged by the data from the North Devon Lowlands. Conventional reconstructions of High Arctic prehistory (e.g., McGhee, 1976, 1979; Maxwell, 1985) argue that portions of the Canadian Arctic were initially populated by two related, but very distinct, Early Palaeo-Eskimo groups - Pre-Dorset in the eastern Central Arctic and Independence $I$ in the High Arctic. In the High Arctic, Independence I is believed to have been displaced, or replaced, by a population movement of PreDorset peoples out of the eastern Central Arctic (most likely from the Foxe Basin/Hudson Straits area). The subsequent history of human occupation in the Arctic Islands is seen as a cyclical sequence of abandonment (or extinction) and recolonization, primarily by eastern Central Arctic populations.

According to this interpretation, much of the temporal variability observed in High Arctic assemblages was a function of new technologies introduced from outside the Arctic Archipelago. The sequence of six Palaeo-Eskimo complexes from the North Devon Lowlands, complemented by Schledermann's (1990) data from the Bache Peninsula area, however, demonstrates that High Arctic Palaeo-Eskimo cultural dynamics were far more complex than this.

A notable feature of the sequence of Palaeo-Eskimo óccupations from the North Devon Lowlands is the observed shifts through time in the extra-regional cultural affiliations of the individual complexes. The Far Site Complex, for example, has been associated with the Independence I Culture, which is primarily (although not exclusively) limited to the High Arctic Islands (including northeast Greenland). The cultural associations of the Icebreaker Beach Complex, on the other hand, have been described as regionally ambiguous. Similarities were noted between this occupational episode and both Independence I and Saqqaq assemblages from Ellesmere Island and West Greenland. Southern influences, possibly originating from Central Canadian Arctic Early to Middle PreDorset complexes, however, were also recognized in the assemblages associated with this complex.

With the Twin Ponds Complex, associations with complexes located to the north and east of the study area apparently ceased. The strongest stylistic affiliations for this complex are, instead, found to the south, in Middle Pre-Dorset assemblages from the western Central Canadian Arctic. There are also strong indications of an in situ development of this complex out of the preceding Icebreaker Beach Complex.

The extra-regional affiliations of the Late Pre-Dorset Rocky Point Complex are likewise oriented southward. Possible ties do, however, extend north to include assemblages from central Ellesmere Island.

Because of the limited sample sizes associated with the Transitional Period Cape Hardy Complex and the Late Dorset Lethbridge Complex, it is impossible to speak with confidence about any extra-regional associations for either occupational episode.
Schledermann (1990) has also noted major shifts through time in the extra-regional cultural affiliations of his Bache Peninsula Palaeo-Eskimo components. Interestingly, these shifts do not parallel exactly those described for the North Devon Lowlands. In the Bache Peninsula sequence, influences stemming from the West Greenlandic Saqqaq Culture were apparently more pronounced and persisted for much longer than was the case in the Devon Island sequence.

The non-synchronous patterns of shifting extra-regional cultural affiliations observed in the North Devon Lowlands and Bache Peninsula Palaeo-Eskimo sequences indicate that variable degrees of in situ development and trait diffusion from several different geographic spheres (facilitated, perhaps, by the widespread practice of a high mobility subsistence/settlement adaptive strategy as outlined above) characterized High Arctic Palaeo-Eskimo prehistory. These data also suggest that local variations in the history of external contacts and in situ cultural developments have introduced a significant degree of intra-regional variability into the archaeological record of the Far North. From this it can be concluded that the broad regional models of Palaeo-Eskimo cultural dynamics proposed in the past are empirically inadequate and should be abandoned in favour of more particularistic local reconstructions.

\section{CONCLUDING REMARKS}

It is clear from the preceding discussion that High Arctic Palaeo-Eskimo prehistory was far more dynamic and complex than previously thought. It must be recognized, however, that the typological assessments presented in this paper are based (as are virtually all other comparative assessments of Eastern Arctic artefact assemblages) solely on very informal and largely subjective stylistic comparisons. As argued by Bielawski (1988) and Helmer and Robertson (1990), we actually know very little about the parameters of regional, functional and/or temporal stylistic variation in Palaeo-Eskimo material culture. As a consequence, before we can complete the task of untangling the complex patterns of regional interactions between local occupational sequences, these alternate sources of variation must be identified and controlled for. Until this is accomplished, all our hypotheses about the cultural historical dynamics of Eastern Arctic prehistory must remain at the level of informed conjecture.

\section{ACKNOWLEDGEMENTS}

Major funding for the Devon Island Archaeology Project was provided by the Social Sciences and Humanities Research Council (grants number 410-84-0341 and 410-85-0041). Additional financing was provided by the University of Calgary Research Grants Office, the Science Institute of the Northwest Territories and the Prince of Wales Northern Heritage Centre. The Polar Continental Shelf Project supplied invaluable logistical support while in the field. The Arctic Institute of North America and the Northern Heritage Society were also generous in their long-term support. Thanks also to Drs. Peter Schledermann and Karen McCullough and two anonymous reviewers for their comments on earlier drafts of this paper. Any errors or omissions are, of course, the responsibility of the author.

\section{REFERENCES}

ARUNDALE, W.H. 1981. Radio-carbon dating in Eastern Arctic archaeology: A flexible approach. American Antiquity 46:244-271.

BABB, T.A., and BLISS, L.C. 1974. Susceptibility to environmental impact of the Queen Elizabeth Islands. Arctic 27(3):234-237. 
BIELAWSKI, E.E. 1988. Paleoeskimo variability: The Arctic Small Tool tradition in the central Canadian Arctic. American Antiquity 53:52-74.

BLISS, L.C., ed. 1977. Truelove Lowland, Devon Island, Canada: A High Arctic ecosystem. Edmonton: University of Alberta Press.

COX, S.L. 1978. Paleoeskimo occupations of the North Labrador coast. Arctic Anthropology 15(2):96-118.

FITZHUGH, W. 1972. Environmental archaeology and cultural systems in Hamilton Inlet, Labrador. Smithsonian Contributions to Anthropology No. 16.

1976. Paleoeskimo occupations of the Labrador Coast. In: Maxwell, M.S., ed. Eastern Arctic prehistory: Paleoeskimo problems. Memoirs of the Society for American Archaeology No. 31:103-118.

GRøNNOW, B. 1988. Prehistory in permafrost: Investigations at the Saqqaq site Qeqetasussuk, Disco Bay, West Greenland. Journal of Danish Archaeology 7:24-39.

GRØNNOW, B., and MELDGAARD, M. 1988. Boplads i dybfrost - Fra Christianshab Museums ubgravninger pa Vestgronlands aeldste boplads. Naturens Verden 11-12:409-440.

HANNA, D. 1989. Architectural variability in Paleoeskimo stone circles. Master's thesis, Department of Archaeology, Simon Fraser University, Burnaby, British Columbia.

HELMER, J.W. 1980. Early Dorset in the High Arctic: A report from Kariuk Island, N.W.T. Arctic 33(3):427-442.

1981. Climate change and Dorset culture change in the Crozier Strait region, N.W.T.: A test of the hypothesis. Ph.D. dissertation, Department of Archaeology, University of Calgary, Calgary, Alberta.

1984. Report on the Devon Island Archaeology Project, High Arctic Canada. Paper presented at the 49th Annual Meeting of the Society for American Archaeology, Portland, Oregon.

1986a. A face from the past: An Early Pre-Dorset ivory maskette from North Devon Island, N.W.T. Etudes/Inuit Studies 10(1-2):179-202. 1986b. Final report of the 1985 Devon Island Archaeology Project. End of season report on file at the Archaeological Survey of Canada, Ottawa.

1987a. The Palaeo-Eskimo prehistory of the North Devon Lowlands: Results of the Devon Island Archaeology Project 1982-1986. Paper presented at the 20th Annual Meetings of the Canadian Archaeological Association, Calgary.

1987b. Report on the 1986 Devon Island Archaeology Project. End of season report on file at the Archaeological Survey of Canada, Ottawa. 1988a. A new look at the Independence I and Pre-Dorset occupations of the Canadian Far North. Paper presented at the Sixth Inuit Studies Conference, Copenhagen, Denmark.

1988b. The Jones Sound Archaeology Project. End of season report on file at the Archaeological Survey of Canada, Ottawa.

1990. Patterns of prehistoric land use in a High Arctic oasis. Paper presented at the 23rd Annual Meetings of the Canadian Archaeological Association, Whitehorse, Yukon.

In press. Prehistoric site location strategies in the North Devon Lowlands, High Arctic Canada: A socioecological perspective. Journal of Field Archaeology.

HELMER, J.W., and KENNEDY, B.V. 1986. Early Paleoeskimo skeletal remains from north Devon Island, High Arctic Canada. Canadian Journal of Archaeology 10:127-143.

HELMER, J.W., and ROBERTSON, I.G. 1990. Quantitative shape analysis of Early Palaeo-Eskimo endblades. Canadian Journal of Archaeology 14:107-122.

KNUTH, E. 1967. Archaeology of the Musk-ox Way. Paris: Contributions du Centre d'Etudes Arctiques et Finno-Scandinaves, No. 5.

1968. The Independence II bone artifacts and the Dorset evidence in North Greenland. Folk 19:61-81.

1977/78. The "Old Nugdlit Culture" site at Nugdlit Peninsula, Thule District and the "Meso-Eskimo" site below it. Folk 19/20:15-47.

LETHBRIDGE, T.C. 1939. Archaeological data from the Canadian Arctic. Joumal of the Royal Anthropological Institute of Great Britain and Ireland 69(2):187-233.

LOWTHER, G.R. 1962. An account of an archaeological site on Cape Sparbo, Devon Island. Ottawa: National Museum of Canada Bulletin 180:1-19. 1965. The prehistory of Cape Sparbo. North 12(6):38-42.

MAXWELL, M.S. 1985. Prehistory of the Eastern Arctic. New York: Academic Press.

McCARTNEY, P.H. 1989. Paleoeskimo subsistence and settlement in the High Arctic. Ph.D. dissertation, Department of Archaeology, University of Calgary, Calgary, Alberta.

MCCARTNEY, P.H., and HELMER, J.W. 1989. Marine and terrestrial mammals in High Arctic Paleoeskimo economy. Archaeozoologia 3(1/2):143-160.
McCULLOUGH, K., and SCHLEDERMANN, P. 1989. The Ellesmere Island Research Project final report on the 1988 field season. Unpubl. ms. on file at the Arctic Institute of North America, Calgary, Alberta.

McGHEE, R. 1970. Excavations at Bloody Falls, N.W.T., Canada. Arctic Anthropology 6(2):53-72.

1976. Paleoeskimo occupations of Central and High Arctic Canada. In: Maxwell, M.S., ed. Eastern Arctic prehistory: Paleoeskimo problems. Memoirs of the Society for American Archaeology 31:15-39.

1979. The Paleoeskimo occupations at Port Refuge, High Arctic Canada. Archaeological Survey of Canada Mercury Series Paper 6. Ottawa: National Museums of Canada.

1981. The Dorset occupations in the vicinity of Port Refuge, High Arctic Canada. Archaeological Survey of Canada, Mercury Series Paper 105. Ottawa: National Museums of Canada.

McGHEE, R., and TUCK, J. 1976. Un-dating the Canadian Arctic. In: Maxwell, M.S., ed. Eastern Arctic prehistory: Paleoeskimo problems. Memoirs of the Society for American Archaeology 31:6-14.

MELDGAARD, J. 1960. Prehistoric sequences in the Eastern Arctic as elucidated by stratified sites at Igloolik. Selected Papers of the 5th International Congress of Anthropological and Ethnological Sciences, 1956. Philadelphia: University of Pennsylvania Press.

1983. Qaja, en kokkenmodding i dybfrost. Copenhagen: Feltrapport fra arbejdsmarken i Gronland, Saertryk af National Museet, Arbejdsmark.

MEYER, D. 1977. Pre-Dorset settlements at the Seahorse Gully Site. Archaeological Survey of Canada, Mercury Series Paper 57. Ottawa: National Museums of Canada.

MÜLLER-BECK, H. 1977. Excavations at Ummingmak on Banks Island, N.W.T., 1970 and 1973: Preliminary report. Urgeshichtiche Materialhefte 1. Tübingen: Verlag Archaeologica Venatoria, Institut für Urgeschichte der Universitat Tübingen.

PARK, R.W. 1986. Report on the Northern Heritage Research Project's excavation at Truelove Lowland, Devon Island, N.W.T., 1986. End of season report to the Prince of Wales Northern Heritage Centre, Yellowknife, Northwest Territories.

PLUMET, P. 1969. Archéologie de l'Ungava: Le problème des maisons longues à deux hémicycles et séparations intérieures. Paris: Contributions du Centre d'Etudes Arctiques et Finno-Scandinaves, No. 7.

1985. Le Site de la Pointe aux Bélougas (Qilalugarsiuvik) et les maisons longues Dorsétiennes. Montreal: Collection Paléo-Québec 18.

ROBERTSON, I.G. 1989. Metric variability in Arctic Small Tool tradition spalled burins: A preliminary shape analysis. Master's thesis, Department of Archaeology, University of Calgary, Calgary, Alberta.

ROUSE, I. 1972. Introduction to prehistory: A systematic approach. New York: McGraw-Hill Book Company.

SCHLEDERMANN, P. 1978a. Preliminary results of archaeological investigations in the Bache Peninsula region, Ellesmere Island, N.W.T. Arctic $31: 459-474$

1978b. Prehistoric demographic trends in the Canadian High Arctic. Canadian Journal of Archaeology 2:43-58.

1987. The Arctic Small Tool tradition in the Bache Peninsula region, Ellesmere Island, N.W.T. Paper presented at the 20th Annual Meetings of the Canadian Archaeological Association, Calgary, Alberta.

1990. Crossroads to Greenland: 3000 years of prehistory in the Eastern High Arctic. Komatik Series No. 2. Calgary: Arctic Insitute of North America.

SCHLEDERMANN, P., and McCULLOUGH, K. 1988a. The Ellesmere Island Research Project final report on the 1987 field season. Unpubl. ms. on file at the Arctic Institute of North America, Calgary, Alberta.

1988b. Hearth of darkness: Structural variability in ASTt dwellings in the Canadian High Arctic. Paper presented at the 21st Annual Chacmool Conference, Calgary, Alberta.

TAYLOR, W.E., Jr. 1967. Summary of archaeological fieldwork on Banks and Victoria Islands, Arctic Canada, 1965. Arctic Anthropology 4(1):221243.

1968. The Arnapik and Tyara sites: An archaeological study of Dorset Culture origins. Memoirs of the Society for American Archaeology 22.

1972. An archaeological survey between Cape Parry and Cambridge Bay, N.W.T., Canada. Archaeological Survey of Canada, Mercury Series Paper 1. Ottawa: National Museums of Canada.

TUCK, J.A. 1975. Prehistory of Saglek Bay, Labrador: Archaic and Paleoeskimo occupations. Archaeological Survey of Canada, Mercury Series Paper 32. Ottawa: National Museums of Canada.

WINTERHALDER, B., and SMITH, E.A. 1981. Hunter-Gatherer foraging strategies. Chicago: University of Chicago Press. 